\title{
WOMEN IN COMbat: IS THe CURRENT Policy ObSOleTe?
}

\author{
MARTHA MCSALLY*
}

INTRODUCTION 1012

I. CURRENT CONTEXT OF THE DEBATE ON WOMEN IN GROUND COMBAT ..........1014

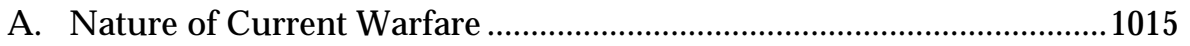

B. Women's Performance in Iraq and Afghanistan ....................................1017

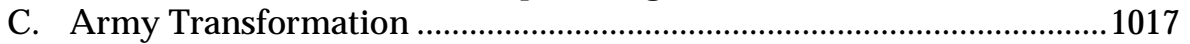

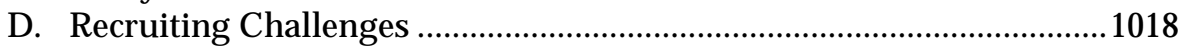

II. HistORY OF U.S. LAW AND POLICY AND WOMEN'S ROLES IN THE

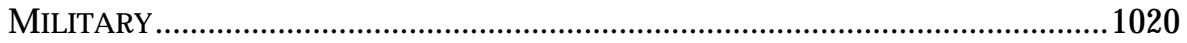

III. ANALYSIS OF THE GROUND COMBAT EXCLUSION POLICY ................................1028

A. Physical Strength.......................................................................................1029

1. Military effectiveness requires that we pick the best qualified

person for the job, regardless of gender...

2. This argument was used to keep women out of fighter aircraft in

the early 1990s and proved to be wrong .................................................1030

3. All relevant qualities should be considered .............................................1032

4. The author's personal experience ...........................................................1033

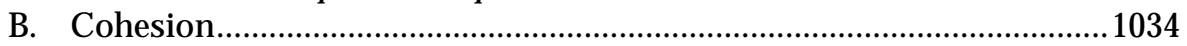

1. Military cohesion is based on people uniting for a common mission or purpose, not based on the group consisting of a common race, creed, or gender ...............................................................1035

2. Cohesion is a leadership issue ..............................................................1036

3. This argument was used to keep all women out of fighter aircraft in the early 1990s and was proven wrong.....

4. The author's personal experience

* Colonel, United States Air Force. The views expressed in this Article are those of the author personally and are not intended to represent the views of the United States Department of Defense or the United States Air Force.

I would like to thank several people for their comments on earlier drafts of this Article. As a disclaimer, not all of the following individuals agreed with all of my recommendations regarding women in the military. Special thanks go to Dr. Gary Schaub, my faculty advisor at the Air War College, for pushing me to publish a quality product. Also, thanks to the Women In Military Service For America Memorial Foundation, led by Brig. Gen. Wilma Vaught, U.S. Army (Ret.), for honoring all American women who served in uniform. Gen. Vaught also vetted my historical section and provided valuable inputs for the rest of the paper. Also, thanks to: Darlene Iskra, Cmdr., U.S. Navy (Ret.); Lory Manning, CAPT., U.S Navy (Ret.); Michael Isherwood, Col., U.S. Air Force (Ret.); Rosemary Mariner, CAPT., U.S. Navy (Ret.); Lory Fenner, Col., U.S. Air Force (Ret.); Christopher Haave, Col., U.S. Air Force; Edward Kertis, Col., U.S. Army; William Stowman, Lt. Col., U.S. Army; Robert Labrutta, Col., U.S. Air Force; Diane Ficke, Lt. Col., U.S. Air Force; and Earl Comstock, Esq. Finally, I would like to thank Vincent DeMore, Boston University School of Law Class of 2007, for his tireless assistance in conducting legal research and citation verification for me. 
C. Women Just Don't “Belong” In Combat .....................................................1041

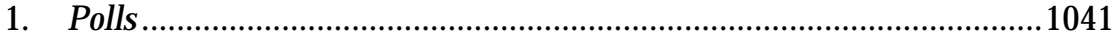

2. Body bags .........................................................................................1043

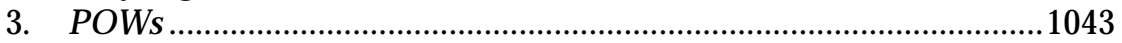

IV. GENDER ISSUES AND POLICIES THAT DEGRADE COMBAT EFFECTIVENESS..........1044

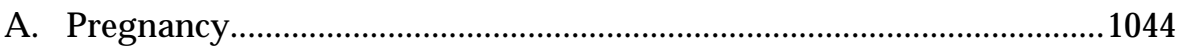

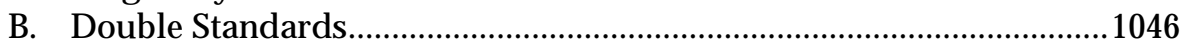

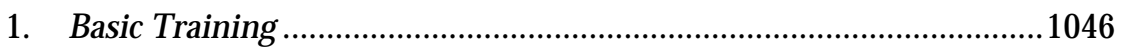

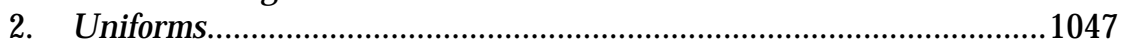

3. Double standards that demean or patronize female warriors .................1048

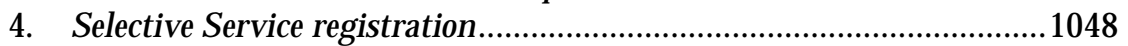

V. POLICY AND LEGISLATIVE RECOMMENDATIONS .............................................1050

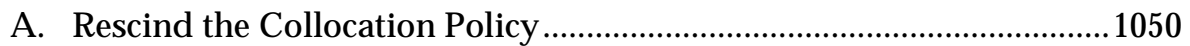

B. Adopt Gender-Neutral Criteria for Assignments ................................1050

C. Rescind the Ground Combat Exclusion Policy ........................................1051

D. Rescind the Policy that Permits Servicewomen to Avoid their

Commitments Due to Pregnancy..............................................................1051

E. Eliminate Double Standards...................................................................1051

F. Amend the Military Selective Service Act to Include Women .............1052

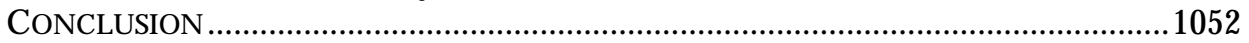

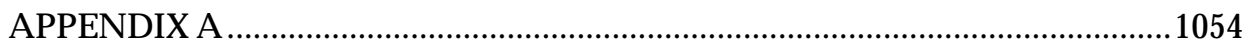

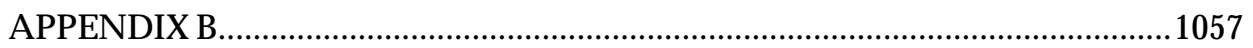

\section{INTRODUCTION}

In January 2005, during an interview with The Washington Times regarding the war in Iraq and recent transformations within the Army, President Bush stated: "There's no change of policy as far as I'm concerned. No women in combat." ${ }^{1}$ Technically, the policy has not changed, but in reality, the nation's policy has not survived contact with the enemy. As Commander-in-Chief, the President has engaged military power in the war against terrorism on a global scale, and the conflicts in Afghanistan and Iraq have engulfed both men and women in combat.

Operations ENDURING FREEDOM (Afghanistan) and IRAQI FREEDOM (Iraq) are the first major combat operations since hundreds of thousands of new positions in the military were opened to women in the 1990s. Women have deployed and fought as fighter, bomber, attack, and helicopter pilots in all the services, in ground combat support positions, and aboard combat and support Navy and Coast Guard vessels. According to the Department of Defense (DoD), in May 2006, 10,100 women were deployed to Iraq, and 1900 women were

1. Rowan Scarborough \& Joseph Curl, Despite Pressure, Bush Pledges "No Women in Combat," WASH. TIMES, Jan. 12, 2005, at A01. 


\section{WOMEN IN COMBAT: IS THE CURRENT POLICY OBSOLETE? 1013}

deployed to Afghanistan, constituting eight percent of the total force. ${ }^{2}$ In total, over 155,000 women have served in Iraq and Afghanistan since 2002. ${ }^{3}$

American women have fought and served in every U.S. war, beginning with the Revolutionary War. Today, there are over 198,000 women in the active duty military, constituting $14.5 \%$ of the active force. ${ }^{4}$ Women are integral members of the armed forces, serving as Airmen, Soldiers, Sailors, and Marines, and they are here to stay. Yet despite women's accomplishments throughout history, and most recently in the War on Terror, DoD policy still prohibits women from serving in approximately 200,000 positions in the military. ${ }^{5}$

In this Article, I will answer the following question: "Should women continue to be prohibited from serving in 'ground combat' units based only on their gender?" The answer I provide begins by placing today's policy into context, summarizing the major laws and policies related to women in the military, and reviewing the history of the expanding roles of women in the military. I then analyze the ground combat exclusion policy and discuss some of the gender-related DoD policies that, in my opinion, hinder the full integration of women into the military as respected warriors. Finally, I provide some policy and legislative recommendations to further increase American military effectiveness.

I had the privilege of being one of the first women to become a fighter pilot in the United States Air Force (USAF) and the first woman in U.S. history to fly a fighter aircraft into combat. In June 2006, I completed a tour as the first woman to command a combat aviation squadron, during which I led my A-10 fighter squadron into combat in Afghanistan in $2005 .{ }^{6}$ My assignment as a female frontline warrior and the highest-ranking female combat pilot in the USAF enables me to view this issue from both an experiential and a leadership perspective. My

2. Joint Staff Information Paper on Women in Combat, May 3, 2006 [hereinafter Joint Staff Information Paper] (on file with author).

3. Sharon Cohen, Associated Press, Women Take on Major Battlefield Roles, WASH. POST (online ed.), Dec. 2, 2006, available at http://washingtonpost.com/wp-dyn/content/article/2006/12/02/ AR2006120200476.html.

4. Joint Staff Information Paper, supra note 2. The percent deployed to the combat zone is less than the percent in the total force primarily because of a high deployment rate of the types of positions closed to women, especially in the Army and Marines. This imbalance was also an issue in Operation DESERT STORM, where women made up eleven percent of the total force, but only seven percent of the deployed force. A Congressional Research Service (CRS) brief stated this was "because of the exclusion of women from specified combat units, and because services with a smaller percentage of women - the Marines, Navy, and Army-were overrepresented; and the service with the largest percentage of women-the Air Force-was underrepresented, compared to their overall percentage of the armed forces." CRS, Issue Brief for Congress, Women in the Armed Forces (Dec. 12, 1996), available at http://www.fas.org/man/crs/92-008.htm. The CRS brief also stated, "since the main mission of the armed forces is to deter war by being prepared to wage one if it occurs, there is a limit to the extent to which the armed forces can increase the number and expand the assignments of women as long as there are restrictions on assigning women to combat posts." Id.

5. Gen. AcCounting OfFice, NAt'L SeC. \& INT'L AfFAIRS Div., GENDER ISSUES: INFORMATION ON DOD's AssignMENT POLICY AND DiReCt GROUND COMBAT DEFINITION 4 (1998) [hereinafter GAO, GENDER ISSUES], available at http:/ / www.gao.gov/archive/1999/ns99007.pdf.

6. The A-10 is a single-seat attack aircraft that was designed to integrate with combat ground forces to kill the enemy in close combat, providing Close Air Support. It carries 1174 rounds of $30 \mathrm{~mm}$ bullets and a variety of other bombs, missiles, and rockets. 
personal experiences as a combat pilot and military commander frame my analysis.

\section{CURRENT CONTEXT OF THE DEBATE ON WOMEN IN GROUND COMBAT}

DoD's most recent version of the "ground combat exclusion policy" was established in 1994. The DoD policy states:

Service members are eligible to be assigned to all positions for which they are qualified, except that women shall be excluded from assignment to units below the brigade level whose primary mission is to engage in direct combat on the ground ....?

The policy goes on to define "direct combat" as

engaging an enemy on the ground with individual or crew served weapons, while being exposed to hostile fire and to a high probability of direct physical contact with hostile force's personnel. Direct ground combat takes place well forward on the battlefield while locating and closing with the enemy to defeat them by fire, maneuver, and shock effect.

The policy then adds these additional restrictions:

These policies and regulations may include the following restrictions on the assignment of women:

- Where the Service Secretary attests that the costs of appropriate berthing and privacy arrangements are prohibitive;

- Where units and positions are doctrinally required to physically collocate and remain with direct ground combat units that are closed to women;

- Where units are engaged in long range reconnaissance operations and Special Operations Forces missions; and

- Where job related physical requirements would necessarily exclude the vast majority of women service members.

This policy translates into the exclusion of women from infantry, tank (armor), and artillery units below the brigade level in the Army and Marine Corps, Navy submarines and other ships with close quarters, and Special Forces units in all the service branches. ${ }^{10}$ Additionally, as a matter of policy, women are excluded from serving in support units that collocate with any of these ground combat units. This particular restriction, referred to as the "collocation policy," is one of the most contentious in the current War on Terror. ${ }^{11}$

7. Memorandum from Secretary of Defense Les Aspin to the Secretaries of the Army, Navy, and Air Force et al., Direct Ground Combat Definition and Assignment Rule (Jan. 13, 1994) [hereinafter Direct Ground Combat Definition and Assignment Rule]. See also generally Assignment of Army and Marine Corps Women Under the New Definition of Ground Combat: Hearing Before the Subcomm. on Mil. Forces \& Personnel of the H. Comm. on the Armed Servs., 103d Cong. (Oct. 6, 1994).

8. Direct Ground Combat Definition and Assignment Rule, supra note 7.

9. Id.

10. The Army is organized into units in the following order, from largest to smallest: army, corps, division, brigade, battalion, company, platoon, and squad.

11. For an extensive list of all jobs and units currently closed to women, see Appendix A. 


\section{WOMEN IN COMBAT: IS THE CURRENT POLICY OBSOLETE? 1015}

In Spring 2005, Rep. Duncan Hunter (R-Cal.), then Chairman of the House Armed Services Committee (HASC), and Rep. John McHugh (R-N.Y.), then Chairman of the HASC Subcommittee on Military Personnel, introduced a nonotice amendment to the 2006 Defense Authorization Bill that, if passed, would have codified a ground combat exclusion for the first time in U.S. history and prohibited women from serving in Army forward support companies. This move gained immediate public attention and provoked strong objections from Army leadership, DoD leadership, and many members of Congress. According to The Washington Post, Army Lt. Gen. James L. Campbell, Director of the Army Staff, quickly delivered a letter to ranking Democrat Rep. Ike Skelton (D-Mo.) stating that, if the amendment passed, "a total of 21,925 spaces currently open for assignment to female soldiers would be closed."12 Retired General Gordon Sullivan, former Army Chief of Staff and President of the Association of the United States Army, also wrote a letter to the House Armed Services Committee stating that the amendment would be "confusing"13 and "detrimental to units." In the end, McHugh and Hunter's efforts were thwarted; the final amendment was a significant compromise. It mandated that the DoD notify Congress of any opening or closing of positions or units under the ground combat exclusion policy that came into effect on October 1, 1994. However, it also mandated notification of any change that opened or closed any career fields related to military operations on the ground after May 18, 2005. ${ }^{15}$ This requirement was unprecedented because Congress had previously wanted notification only on changes to ground combat positions, and not on all career fields related to military operations on the ground (which includes essentially all Army and Marine positions). The amendment represented significant Congressional oversight of military personnel matters.

The debate on whether women should serve in "ground combat" continues, and the issue will likely be revisited by Congress and the DoD. Policymakers should take into consideration the nature of current warfare, women's performance in Iraq and Afghanistan, the transformation of the Army, and the challenges of recruiting in wartime for an all-volunteer force.

\section{A. Nature of Current Warfare}

In wars like those in Iraq and Afghanistan, there is no "forward area" on the battlefield. Today's battlefield is non-linear and occurs in a 360-degree radius around the troops. Despite the ground combat exclusion policy, women are serving in real ground combat every day. They are vulnerable to being injured, killed, or captured; they are being shot at in ambushes and hit by improvised explosive devices (IEDs); they are employing their weapons and killing the enemy. Indeed, in the words of James Wise, Jr., and Scott Baron in the preface of their new book Women at War, "[t]he insurgency war in Iraq, which has no front lines, has made the debate regarding women in combat

12. Ann Scott Tyson, More Objections to Women in Combat Ban, WASH. POST, May 18, 2005, at A5.

13. $I d$.

14. Id.

15. National Defense Authorization Act for Fiscal Year 2006, Pub. L. No. 109-163, 119 Stat. 336 (2006). 
irrelevant."16 Or as Lt. Dawn Halfaker, an Army military police officer who lost her right arm during a rocket-propelled grenade attack while on a reconnaissance mission in Iraq, put it: "Women in combat is not really an issue. It is happening. Everyone pretty much acknowledges there are no rear battle areas, no forward line of troops."17

Based on the current policy, women serve as gunners on truck convoys and as security forces or military police on patrol in the streets of Baghdad, but they cannot be assigned to multiple-launcher rocket system positions. They are vital to conducting searches at checkpoints in Iraq, a site of many insurgent attacks, since there would be strategic consequences if American men searched Iraqi women. Yet, they cannot serve in reconstruction efforts as combat engineers. Paradoxically, women fly Apache helicopters and kill the enemy while facing a high risk of being shot down, but they are prohibited from flying specialoperations helicopters. The policy excludes women from being in ground units that have an offensive capability, but they can be in units that can and do fight in a defensive posture. This is reminiscent of earlier restrictions for women pilots, who could fly helicopters, tankers, reconnaissance, and cargo aircraft into enemy territory at risk of being shot down, but could not fly aircraft that could shoot back.

Trying to restrict women to defensive positions to avoid the risk of combat is ineffective in protecting women from the dangers of war. ${ }^{18}$ As of February 12, 2007, seventy-five U.S. military women had been killed in action in Iraq and Afghanistan, ${ }^{19}$ and two had been captured as Prisoners of War (POWs). ${ }^{20}$ As of December 2, 2006, more than 430 women have been wounded in battle. ${ }^{21}$ The military is now training all troops in basic combat skills, since recent war

16. JAMES E. WiSE, JR. \& SCOTT BARON, WOMEN AT WAR ix (2006) (alteration added).

17. David Moniz, Female Amputees Make Clear That All Troops Are On Front Lines, USA TODAY, Apr. 28, 2005, at 1A.

18. Women constitute eight percent of the deployed force but only two percent of fatalities in recent years. Therefore, some argue, the direct ground combat exclusion is protecting women from the dangers of war. This argument is flawed for three reasons. First, the relationship between the combat exclusion and the number of female fatalities has yet to be fully analyzed. Second, implicit in this argument is the unprincipled assumption that a death toll of seventy-five women is acceptable but that a death toll of 300 would be unacceptable. And third, the combat exclusion may, in some circumstances, actually place women at increased risk. Consider the following example. On June 23, 2005, a suicide car bomber struck a U.S. convoy in Falluja, Iraq, killing four marines, including three women. See Female Troops in Iraq Exposed to Combat, CNN.COM, June 28, 2005, http:/ /www.cnn.com/ 2005/WORLD/meast/06/25/women.combat. Another eleven women were injured. Id. It was the deadliest day for U.S. servicewomen since World War II. These women were on route to their posts at checkpoints where they performed the important-and culturally sensitive-task of searching female Iraqi civilians. Ironically, because current policy prohibits the collocation of women with small combat units, these women were transported dangerous distances instead of being collocated with the all-male units they support. I will discuss more fully American public opinion regarding women casualties in Part III.C, infra.

19. The World: Women in Combat (BBC News radio broadcast Feb. 12, 2007) (transcript and audio available at http:/ / www.theworld.org/?q=node/7962).

20. The NewsHour with Jim Lehrer: Women Warriors (PBS television broadcast Apr. 17, 2003) (statement of Betty Ann Bowser) (transcript available at http://www.pbs.org/newshour/bb/ military/jan-june03/women_4-17.html).

21. Cohen, supra note 3. 


\section{WOMEN IN COMBAT: IS THE CURRENT POLICY OBSOLETE? 1017}

experiences indicate that anyone can find himself or herself in close combat, regardless of whether they are specifically assigned to "combat" or "combat support" units. Women are already in ground combat, and they are showing impressive results. ${ }^{22}$

\section{B. Women's Performance in Iraq and Afghanistan}

Policy discussions must consider the performance of women in recent conflict. Women are displaying great courage and skill in ambushes, firefights, and battles on the ground. They are not just surviving, but earning medals for valor in combat. On March 20, 2005, Army Sgt. Leigh Ann Hester was in a convoy of twenty-six vehicles that came under enemy ambush by fifty insurgents. ${ }^{23}$ Sgt. Hester "led her team through the 'kill zone' and into a flanking position, where she assaulted a trench line with grenades and M203 grenadelauncher rounds. Sgt. Hester killed at least three insurgents ${ }^{\prime 24}$ and was awarded the Silver Star for her bravery under fire. In 2003, Army Airborne Capt. Kellie McCoy earned a Bronze Star with a combat "V" for Valor for her actions in Fallujah: "Leading a patrol that got ambushed and took casualties, she hopped up into the Humvee's machine gun turret, killed a couple of the attackers, then led her men to safety." ${ }^{26}$ As of December 18, 2006, the Army had awarded women warriors one Silver Star, seven Bronze Stars with Valor, thirteen Air Medals with Valor, and sixty-eight Army Commendation medals with Valor. ${ }^{27}$

\section{Army Transformation}

The discussion of the ground combat exclusion policy is complicated by a significant transformation in Army organization and warfighting concepts. The

22. Opponents of women in ground combat argue that sustaining and returning fire while in a defensive posture is normatively distinct from seeking out and killing the enemy while in an offensive posture. For example, when testifying before the 1992 Presidential Commission on the Assignment of Women in the Armed Forces, Vietnam veteran retired Marine Sgt. Major Overstreet stated:

“We say, 'Combat is combat is combat.' I'm here to tell you, it is not. First of all, I'm here to tell you that it is one thing to be in a combat area; it's another thing to be in a combat area and have rounds coming in on you. It's even another thing to send rounds downrange. But, it's a little bit different when you know you are the guy that is going to have to seek out, close with, and do whatever it takes to the enemy. You. You are going to go out there and confront him, one on one. You realize that this is no game, there is no second place, and if you are second place, you don't come back."

Presidential COMmission on the Assignment of WOMEN IN THE ARMED ForCes, Report to the PRESIDENT: WOMEN IN COMBAT (1992) [hereinafter PRESIDENTIAL COMMISSION REPORT]. Ironically, the "enemy" to which Sgt. Major Overstreet referred included a significant number of Vietnamese women. See Appendix B. While the author appreciates the distinction between offensive and defensive posture, the author does not believe that traditional norms regarding the "proper" roles of men and women should inform military personnel assignments.

23. 151 CONG. REC. E1492 (daily ed. July 14, 2005) (statement of Rep. Cooper).

24. $I d$.

25. Brad Knickerbocker, Do U.S. Women Belong in the Thick of the Fighting?, CHRISTIAN SCI. MONITOR, May 26, 2005, at 1.

26. Id.

27. Telephone Interview with Army G-1 staff (Dec. 18, 2006). 
Army is now transforming to a modular organization of Brigade Combat Teams (BCTs) in an effort to become a lighter, leaner, more agile force. ${ }^{28}$ In this new organization, the current combat restrictions for women are harder to comply with without closing a significant number of positions now open to women. The Army is delicately dealing with this issue by assigning all forward support companies (FSCs) to the brigade level in the BCT construct in order to stay within the letter of the collocation policy. This Army decision motivated the 2005 Hunter-McHugh Amendment, elicited criticism that the Army is circumventing the DoD policy and Congressional notification requirements, and sparked the recent debate on the ground combat exclusion policy. ${ }^{29}$

\section{Recruiting Challenges}

Finally, policy discussions concerning the ground combat exclusion for women must factor recruiting into the dialogue. Maintaining recruiting quality in the All-Volunteer Force during wartime has been a challenge for the Army in particular. New enlisted recruits take an Armed Forces Qualification Test (AFQT) which measures their overall aptitude. Recruits earn a percentile score of one to ninety-nine and are placed into one of six categories: I (scoring 93-99); II (65-92); IIIA (50-64); IIIB (31-49); IV (10-30); or V (1-9). ${ }^{30}$ Category V recruits are ineligible for service. ${ }^{31}$ Since 1991, the DoD capped Category IV recruits at two percent of the total. ${ }^{32}$ The DoD also desires that ninety percent of recruits have high school diplomas. ${ }^{33}$ Finally, although the DoD accepts recruits with criminal records, medical issues, or drug and alcohol problems via a waiver process, it desires to minimize these numbers.

The Army's recruiting difficulties can be seen in changes to these indicators. In 2004, ninety-two percent of Army recruits graduated from high

28. Under the old Army organization, the Division was the basic deployable warfighting unit. The new design has the Brigade as the basic warfighting unit. Therefore, a number of combat support functions that used to be at the division and brigade level are now assigned to the brigade and battalion level. FSCs are combat support units whose functions were previously attached to the brigade and division level and were open to women. The Army is attaching the FSCs to the brigade level (instead of battalion), thereby keeping the positions open to women, since the current combat exclusion policy restricts women from combat units or support units that collocate with combat units below the brigade level.

29. For example, Elaine Donnelly, President of the Center for Military Readiness, has accused the Army of circumventing DoD policy and Congressional notification requirements based on the FSC policy decision. See Elaine Donnelly, Center for Military Readiness, Questions About Pentagon Violations of Policy and Law (Mar. 1, 2006), http://cmrlink.org/WomenInCombat.asp?docID=262.

30. See Dep't of Defense Instruction 1145.01, at $\S 4$ (2005), available at http://www.dtic.mil/ whs/directives/corres/pdf/114501p.pdf; see also id. at encl. 1, II E.1.1.1 (providing the numerical standards cited in text).

31. Id. at $\S 4.1$.

32. Dep't Of Defense, Population Representation in the Military SERVices, at app. D Table D-7 (2003) ("NPS Active Component Enlisted Accessions by AFQT Category, FYs 1973-2003"), available at http://www.dod.mil/prhome/poprep2003/appendixd/d_07.html.

33. Joint Chiefs of Staff, Directorate for Manpower and Personnel (JCS/J1), Recruiting, Retention, and End Strength Report (Oct. 11, 2006) [hereinafter JCS/J1, Recruiting, Retention, and End Strength Report] (on file with author). The JCS/J1 produces this report weekly and monthly for the Chairman of the Joint Chiefs of Staff. 


\section{WOMEN IN COMBAT: IS THE CURRENT POLICY OBSOLETE? 1019}

school, $0.6 \%$ were in Category $\mathrm{IV}^{34}$ and twelve percent required waivers for criminal offenses, drug or alcohol-related violations, or medical conditions. ${ }^{35}$ In 2005, the Army fell short of its recruiting goals for the first time since 1979. ${ }^{36}$ In order to meet subsequent goals, the DoD raised the Category IV cap to four percent in $2005 .^{37}$ In fiscal year 2006, the Army met its overall recruiting goal. ${ }^{38}$ However, only $81.2 \%$ of Army recruits graduated from high school, ${ }^{39} 3.7 \%$ were in Category $\mathrm{IV}^{40}$ and seventeen percent required waivers. ${ }^{41}$ The Army has struggled to recruit adequate numbers of high-quality personnel, which will be more of a challenge if the Army end strength is increased by 65,000 troops, as requested by Secretary of Defense Gates in January 2007..$^{42}$ These manpower challenges sparked recent proposals to reinstitute the draft. However, utilizing all volunteers, including both men and women, to maximize flexibility and capability should be considered prior to abandoning the All-Volunteer Force established thirty-four years ago.

The realities of current combat, the performance of women in Iraq and Afghanistan, Army transformation, and the challenges of meeting recruiting goals in an all-volunteer force provide the context for discussing and analyzing the ground combat exclusion policy. In order to fully analyze the current restrictions on women in combat, one must be familiar with how and why relevant law and policy evolved. Laws and policies on women in the military reflect issues of military readiness as well as a complex set of attitudes, emotions, culture, and politics about whether women "could" or "should" serve in certain roles.

34. Fred Kaplan, GI Schmo: How Low Can Army Recruiters Go?, SLATE (online), Jan. 9, 2006, http://www. slate.com/id/2133908/.

35. Anna Badkhen, Army Relaxes Its Standards to Fill Ranks: Critics Say Push to Meet Quotas May Let Unstable Recruits Join Up, S.F. CHRON. (online ed.), July 11, 2006, http://sfgate.com/cgibin/article. cgi?file=/c/a/2006/07/11/MNG03JT3ER1.DTL.

36. Associated Press, Lower Standards Help Army Meet Recruiting Goal, USA TODAY (online ed.), Oct. 9, 2006 [hereinafter Associated Press, Lower Standards], available at http:/ /www.usatoday.com/ news/washington/2006-10-09-army-recruiting_x.htm?csp=34.

37. $I d$.

38. See JCS/J1, Recruiting, Retention, and End Strength Report, supra note 33.

39. Id.

40. $I d$.

41. Associated Press, Lower Standards, supra note 36.

42. Rowan Scarborough, Gates Requests 92,000 Increase in Active Forces, WASH. TIMES, Jan. 12, 2007, at A06. 


\section{History OF U.S. LAW AND POLICY AND WOMEN'S ROLES IN THE MiLitary ${ }^{43}$}

During the Revolutionary War, American women served on the battlefield as cooks, nurses, water-bearers, laundresses, and spies. Margaret Corbin and Deborah Sampson were the most well-known women who fought in the Revolutionary War. Corbin took over her husband's artillery position after he was killed in the battle of Fort Washington; she was later wounded herself. She was the first woman in America to receive a military pension for her service. ${ }^{44}$ Sampson disguised herself as a man and served for three years, fighting in many battles before she was hospitalized and discovered to be a woman. She was quietly discharged.

In the Civil War, many women fought on both sides by disguising themselves as men. Women also served in the traditional roles as nurses, cooks, and laundresses, and were used as spies, couriers, and saboteurs: "They blew up bridges, cut telegraph wires, burned arsenals and warehouses, and helped prisoners and slaves escape. ${ }^{\prime \prime 5}$ The most famous military servicewoman of the Civil War was Dr. Mary Walker, who is still the only woman to be awarded the nation's highest military award, the Congressional Medal of Honor. Walker, a medical doctor with the Union Army, served in several major battles and was eventually captured and held as a POW.

During the Spanish-American War, Congress authorized the contracting of female nurses to support the war due to typhoid fever epidemics among the troops and the shortage of medical personnel. Although these nurses were not given military status, over 1500 women served in the United States, overseas, and on hospital ships. ${ }^{46}$ Twenty women died while serving in the war, mostly of typhoid fever. ${ }^{47}$ As a result of the service of these women, Congress authorized a permanent Army Nurse Corps in 1901 and a Navy Nurse Corps in 1908.

In World War I, nearly 23,000 women served as nurses at home and overseas. ${ }^{48}$ Women also served as yeomen and clerks on the home front, in addition to serving as contract telephone operators and stenographers in Europe. Thirty-four thousand women served in uniform by the end of the war, ${ }^{49}$ and four hundred U.S. women died while serving their country-despite not yet

43. Unless otherwise cited, the information in this section was derived from Women in the Military: An Unfinished Revolution. JeAnNe Holm, WOMEN IN THE Military: An UnFINISHed REvolution (Presidio Press rev. ed. 1993). The data in this section was also validated by the President of Women In Military Service For America Memorial Foundation (WIMSA), Brig. Gen. (Ret.) Wilma Vaught. For an extensive history of women in the U.S. military through Desert Storm, see HoLM, supra, or visit the WIMSA Memorial in Arlington, Va. See also WIMSA, About the History of Women Serving in America's Defense, http://www.womensmemorial.org/H\&C/History/ history.html (last visited May 9, 2007).

44. 14 JOURNALS OF THE CONTINENTAL CONGRESS, 1774-1789, at 805 (Worthington C. Ford et al. eds., G.P.O. reprints 1909-37) (1779).

45. HOLM, supra note 43 , at 6 .

46. WIMSA, Highlights in the History of Military Women, http:/ /www.womensmemorial.org/ Education/timeline.html (last visited Mar. 2, 2007) [hereinafter WIMSA, Highlights].

47. $I d$.

48. Id. (noting that 22,956 women nurses served, with 21,480 in the Army and 1476 in the Navy).

49. HOLM, supra note 43 , at 10 . 


\section{WOMEN IN COMBAT: IS THE CURRENT POLICY OBSOLETE? 1021}

having obtained the right to vote: $:^{50}$ "Many Army nurses were decorated, including three who received the Distinguished Service Medal, a combat medal second to the Medal of Honor." ${ }^{\prime 51}$ After the war, all women except nurses were discharged, and laws were passed to prevent their further enlistment. ${ }^{52}$

Women's roles in the military in World War II (WWII) were unprecedented, and their performance laid the foundation for the formal integration of women into the U.S. armed forces after the war. After the attack at Pearl Harbor, Congress established the Women's Army Auxiliary Corps (WAAC) and then the Women Accepted for Volunteer Emergency Service (WAVES), a Navy auxiliary, ${ }^{53}$ but the law forbade women from serving overseas. ${ }^{54}$ In 1943, at Army Chief of Staff Gen. George Marshall's urging, Congress passed a law upgrading the WAAC to the Women's Army Corps (WAC), giving women in the Army a full military status, which included service overseas. ${ }^{55}$ Women also served in uniform as part of the Women's Medical Specialist Corps (WMSC), Marine Corps Women's Reserve, Coast Guard SPARs (from the motto Semper Paratus meaning always ready), and Women Air Force Service Pilots (WASPs). ${ }^{56}$ Over 400,000 women served in WWII ${ }^{57}$-eighty-five were $\mathrm{POWs}^{58}$ and more than 500 women lost their lives in service, sixteen of whom were killed in action. ${ }^{59}$ Although not trained to fight, be under fire, or be POWs, many women demonstrated courage in all theaters during this war. For example, six Army nurses were killed and four were awarded the Silver Star for extraordinary courage under fire following the bombing and strafing of the hospital tents during the battle at Anzio. ${ }^{60}$

The U.S. struggled with the limits of women's roles in WWII. The country trained the WASPs to fly all aircraft in the inventory as ferry pilots, to train male pilots, and to tow planes for anti-aircraft (AA) gunner training, but the U.S. would not allow women to fly in combat like Russian women did. ${ }^{61}$ After the

50. WIMSA, Highlights, supra note 46. Almost all of these deaths were from the flu, not combat action. Id.

51. HOLM, supra note 43 , at 10 .

52. Id. at $16-17$.

53. Id. at 27 .

54. D'Ann Campbell, Women in Combat: The World War Two Experience in the United States, Great Britain, Germany, and the Soviet Union, 57 J. MIL. HIST. 305 (1993).

55. Id. at 305 .

56. WIMSA, Highlights, supra note 46.

57. Id.

58. E-mail from Marilla Cushman, Lt. Col., USA (Ret.), Director of Public Relations and Development, WIMSA, to author (Apr. 13, 2007) (on file with author).

59. WIMSA, Resources: Historical Frequently Asked Questions, http://www.womens memorial.org/?H\&C?Resources/hfaq.html (last visited Apr. 7, 2007).

60. HOLM, supra note 43 , at 92.

61. Holm notes that, overall, WASPs

flew 60 million miles, ferried 12,650 aircraft, towed countless gunnery targets, and instructed hundreds of Air Force pilots. They flew as regularly and as long as male pilots in the same jobs and showed no difference in physical, mental, or physiological capabilities. Although thirty-eight lost their lives, the record shows that the women's accident rate was about the same as the men's. 
British began to train and utilize women to operate AA guns, Gen. Marshall directed a secret experiment to see if American women could fill these positions. "The experiment stunned the general staff: the mixed gender units performed better than all-male units." ${ }^{162}$ The Commander of the experimental units, Col. Timberlake and his superior, Maj. Gen. Lewis, were enthusiastic about the performance of the women and asked Gen. Marshall to allow them to replace "half of the 3630 men in his AA Defense Command with these more efficient soldiers. ${ }^{163}$ Gen. Marshall deliberated with his staff and, based on his difficulty in obtaining approval from Congress to upgrade the WAAC to full military status, gave heavy consideration to the prevailing political climate. As a result, Marshall decided to terminate the experiment. "General Russell Reynolds, Director of the Military Personnel Division, summarized the Army Staff's consensus to eliminate the anti-aircraft experiment before Congress got wind of it: 'It is not believed that national policy or public opinion is yet ready to accept the use of women in field force units.' ${ }^{\prime \prime 64}$

Almost all women were rapidly demobilized after WWII. However, the 1948 Women's Armed Services Integration Act ${ }^{65}$ formally integrated women into the peacetime military for the first time in history. The Act limited women's service in uniform by capping the number of women allowed (two percent of the total force), the number of officers, and the permanent rank they could achieve (lieutenant colonel). ${ }^{66}$ The Act also prohibited women from serving on all Navy ships (except hospital and transport ships) ( $^{67}$ or in "combat aircraft." ${ }^{68}$ The Act did not specifically prohibit women from serving in combat positions

HoLM, supra note 43, at 314-15. For more information on Russian female combat pilots in WWII, see Appendix B.

62. Campbell, supra note 54 , at 302 .

63. Id. at 304 .

64. Id. at 305.

65. Pub. L. No. 80-625, 62 Stat. 356 (1948).

66. HOLM, supra note 43 , at 121.

67. The prohibition from serving on most Navy ships was not included in the original version of the law and was inserted at the whim of Rep. Vinson after an exchange between the Congressman and Navy officials during a hearing. Vinson stated:

I am just throwing it out for what it is worth. Those are my views. I think it will strengthen the bill to have it positively understood by Congress that ships are not places to which these women are going to be detailed and nobody has any authority to detail them to serve on ships. Of course, they are not going to be detailed to serve on ships, but you cannot tell what happens.... [S]omebody might say they need a few of them up there to do communications or other kinds of work and I do not think a ship is a proper place for them to serve. Let them serve on shore in the continental United States and outside of the United States, but keep them off ships. Of course, they ought to be on hospital ships. I would not want to restrict (the prohibition) to combatant vessels. Put down "serve in sea duty." You have auxiliary ships as well as combat ships. Just fix it so they cannot go to sea at all.

Hearing Before the Subcomm. on Org. E Mobilization of the House Comm. on Armed Services, 80th Cong. 5690, 5711 (1948) (statement of Rep. Vinson) (alteration added), quoted in Owens v. Brown, 455 F. Supp. 291, 306 n.53 (D.D.C. 1978). This prohibition-based on the feelings of one Congressmanwould stand as law for thirty years.

68. The services believed that any trained pilot had the potential to be a combat pilot and as a result, banned women from becoming pilots, despite the performance of the WASPs. HOLM, supra note 43 , at 126 . 


\section{WOMEN IN COMBAT: IS THE CURRENT POLICY OBSOLETE? 1023}

on the ground, although that was clearly Congress's intent: "Because the Army was unable to come up with an adequate, acceptable definition of combat, Congress elected to leave this matter to be sorted out by the Secretary of the Army so long as he clearly understood the intent of the Congress, which was no combat for women." ${ }^{\prime \prime 9}$

Many women who served in WWII hoped that the 1948 Integration Act would serve as a springboard for increased integration and equality for women in the military in the future. Instead, women's roles in the military in the 1950s and 1960s reflected women's struggle to be accepted outside their traditional roles. Physical appearance became an important criterion for selection. Women were expected to uphold a feminine image, and women did not receive weapons training. At the start of the Korean conflict, 22,000 women were on active duty performing mostly administrative, medical, communications, or intelligence work. ${ }^{70}$ Some "[s]ervicewomen who had joined the Reserves following World War II [were] involuntarily recalled to active duty during the war." ${ }^{\prime 71}$ However, unlike in WWII, the military decided to deploy only nurses to the war zone-on the ground, on hospital ships, and as flight nurses. Therefore, only "[a]bout 540 women served in the combat zone," while 120,000 women were in uniform during the Korean War era. ${ }^{72}$

The same assumptions about women's roles carried through the Vietnam War, where only approximately 7500 women (mostly nurses) deployed to Southeast Asia. Some women who served during WWII were frustrated by this policy. After she volunteered to deploy but was turned down, one Air Force Master Sergeant said, "I served in North Africa and Italy-I can sure as hell serve in Vietnam." ${ }^{\prime 73}$ From March 1962 to March 1973, only one woman, a nurse, died from hostile fire in Vietnam, as a result of an enemy rocket attack in $1969 .^{74}$ Brig. Gen. Evelyn "Pat" Foote, U.S. Army (Ret.), conveyed her experiences:

When I was in Vietnam in 1967, I was not weapons qualified. In fact, we were not allowed to carry weapons. I was up along the Cambodian border once with a field artillery battalion. The only thing I could do was run around carrying a purse-I called it my "M-16 purse." I was wearing a baseball cap, no helmet, no flak jacket, no weapons, nothing. I was a liability to that unit. Women in the Army don't want to be liabilities. They want to be assets, partners in defense with their male counterparts. ${ }^{75}$

This sentiment is echoed by women in uniform today.

The late 1960s and 1970s were characterized by changes in policy and law that incrementally opened many opportunities to women in uniform. In 1967, an amendment to the Women's Armed Service Integration Act $^{76}$ removed the cap

69. HOLM, supra note 43 , at 119 .

70. ROSEMARIE SKAINE, WOMEN AT WAR: GENDER ISSUES OF AMERICANS IN COMBAT 57 (1999).

71. WIMSA, Highlights, supra note 46 (alterations added).

72. SKAINE, supra note 70 , at 57 .

73. HOLM, supra note 43 , at 210.

74. Her name was Sharon A. Lane, 1st Lt., U.S. Army. SKAINE, supra note 70, at 58.

75. Telephone Interview with Gen. Foote (Jan. 5, 2007).

76. Pub .L. No. 90-130, 81 Stat. 374 (1967). 
on rank and total number of women allowed in uniform. ${ }^{77}$ By 1972, all Reserve Officers' Training Corps (ROTC) programs were opened to women, but scholarship opportunities were limited. ${ }^{78}$ In 1973, the military transitioned from being a mix of draftees and volunteers to an all-volunteer force. ${ }^{79}$ The Army and Navy opened flight training to women. ${ }^{80}$ In 1976, Congress passed a law which admitted women to all service academies, and the Air Force opened flight training to women for the first time in almost thirty years. ${ }^{81}$ Also in 1976, in Crawford v. Cushman, the U.S. Court of Appeals for the Second Circuit considered a challenge to the policy that discharged pregnant servicewomen from the military. ${ }^{82}$ The court ruled that the Marine Corps policy violated the Fifth Amendment Due Process Clause since the policy was based on the impermissible assumption that pregnant women were permanently unfit for military duty. ${ }^{83}$ In 1977, the USAF began to train women as Titan missile crewmembers. ${ }^{84}$ The Army created a combat exclusion policy in 1977, as the WAC was about to be dissolved and women were further integrated into the Army mainstream. This policy stated that: "[w]omen may not serve in Infantry, Armor, Cannon Field Artillery, Combat Engineer, or Low Altitude Air Defense Artillery units of Battalion/Squadron size or smaller. ${ }^{\prime{ }^{85}}$

In 1978, a Navy Interior Communications Electrician, Yona Brown, and other Navy women filed a class action law suit against the Secretary of Defense and the Secretary of the Navy challenging the law that banned women from serving on ships. ${ }^{86}$ Judge John Sirica ruled that the Navy could no longer use this statute as the sole basis for excluding women from serving aboard Navy ships. ${ }^{87}$ In his words, the policy tended "to suggest a statutory purpose more related to the traditional way of thinking of women than to the demands of military preparedness." ${ }^{\prime \prime 8}$ This ruling prompted another amendment to the 1948 Armed

77. Combat Exclusion Laws for Women in the Military: Hearing Before the Subcomm. on Mil. Personnel $\mathcal{E}$ Compensation of the H. Comm. on Armed Services, 100th Cong. 4 (1987) (statement of Martin M. Ferber, Nat'l Sec. \& Int'l Affairs Div., Gen. Accounting Office) [hereinafter House, Combat Exclusion Laws], reprinted in GEN. ACCOUNTING OFFICE, COMBAT EXCLUSION LAWS FOR WOMEN IN THE MiLITARY (1987), available at http:/ /archive.gao.gov/d39t12/134619.pdf.

78. WIMSA, Highlights, supra note 46.

79. Id.

80. HoLM, supra note 43 , at 317,319 .

81. WIMSA, Highlights, supra note 46.

82. Crawford v. Cushman, 531 F.2d 1114 (1976).

83. Id.

84. HOLM, supra note 43 , at 325 .

85. OfFice OF the Deputy Chief of StAFF For Personnel (ARMy), WOMEN IN THE ARMy Policy REVIEW 7 (1982) [hereinafter WITA POLICY REVIEW] (alteration added) (on file with author).

86. See 10 U.S.C. § 6015 (1988), repealed by Pub. L. No. 103-160, § 541(a), 107 Stat. 1659 (1993).

87. Owens v. Brown, 455 F. Supp. 291, 306 (D.D.C. 1978).

88. Id. The opinion in this case provides the foundation for potential future arguments against women in additional combat roles. For instance, Judge Sirica stated:

[B]ecause of section 6015 , sex is required to take precedence over individual ability where the essential part of naval service is concerned. Significantly, none if the limitations and disadvantages facing Navy women is traceable to any studied evaluation made of male and female capabilities that reveals that women lack the native ability to perform competently in positions held exclusively by men.

Id. at 295 (alteration added). 


\title{
WOMEN IN COMBAT: IS THE CURRENT POLICY OBSOLETE? 1025
}

Services Integration Act, ${ }^{89}$ which opened permanent assignments for women on non-combat ships and temporary assignments (less than six months) on combat ships not expected to have a combat mission at the time. ${ }^{90}$

In 1981, then-Army Chief of Staff General Edward Meyer directed the creation of a Women in the Army Policy Review Group (WITA), which was tasked to review issues regarding women in combat and to provide policy recommendations. WITA defined direct combat as

\begin{abstract}
engaging the enemy with individual or crew weapons while being exposed to direct enemy fire, a high probability of direct physical contact with the enemy's personnel, and a substantial risk of capture. Direct combat takes place while closing with the enemy by fire, maneuver, and shock effect to destroy or capture him or while repelling his assault by fire, close combat, or counterattack. ${ }^{91}$
\end{abstract}

Based on this definition, the Army reviewed all Army positions, missions, doctrine, and location and created the Army Direct Combat Probability Code (DCPC) system to identify the probability that each position would be in direct combat. All positions were assigned a code, P1 through P7, where P1 represented the highest probability of engaging in direct combat and P7 the lowest. P1 positions would be off-limits for women. Based on this analysis, WITA concluded that twenty-three additional specialties must be closed to women. ${ }^{92}$ The DCPC is still used today as the means to identify which Army positions are closed to women.

In 1988, the DoD created what is now known as the "risk rule" to further identify and narrow which traditional non-combat positions could be closed to women based on the mission and location of the job on the battlefield. The rule stated that the "risks of exposure to direct combat, hostile fire, or capture are proper criteria for closing non[-]combat positions or units to women, provided that... such risks are equal to or greater than experienced by combat units in the same theater of operations.."193

These policy and legislative lines were not so cleanly drawn on the battlefield. Seven hundred seventy women deployed to Panama in 1989 in support of Operation JUST CAUSE, serving in various "combat support" positions as defined by the $\mathrm{DoD}$ at that time. These women included Army helicopter pilots who earned air medals for "combat missions" and the commander of a military police company. In 1990 and 1991, over forty thousand U.S. military women deployed for Operation DESERT SHIELD/DESERT STORM, constituting seven percent of the total force deployed. Two women in combat support jobs were captured as POWs and thirteen women were killed. ${ }^{94}$

Women's participation and performance in Panama and Iraq helped spark a new discussion on women in combat. "Defense Secretary Dick Cheney said on

89. Pub. L. No. 95-485, 92 Stat. 1611 (1978).

90. House, Combat Exclusion Laws, supra note 77, at 4 (statement of Martin M. Ferber, Nat'1 Sec. \& Int'l Affairs Div., Gen. Accounting Office).

91. WITA POLICY REVIEW, supra note 85 , at 7.

92. Id. at. 8 .

93. HoLM, supra note 43 , at 433 (alteration added).

94. Id. at $455-61,469$. 
2 March 1991, 'Women have made a major contribution to this [war] effort. We could not have won without them.' Commanders in the field echoed similar sentiments. According to the Coalition commander, Gen. H. Norman Schwarzkopf, American military women had performed 'magnificently.'"'195 Congress almost immediately began to consider repeal of the forty-three yearold combat exclusion laws. On December 5, 1991, the president signed the 1992 Defense Authorization Act, ${ }^{96}$ which included a provision repealing the law that prohibited women from flying combat aircraft. ${ }^{97}$ Under the new system, the restriction on women flying combat aircraft was left to the DoD's discretion. The new legislation also directed the creation of a Presidential Commission on the Assignment of Women in the Armed Forces to "study and make recommendations on a wide range of issues relating to service of women in the Armed Forces, with principle focus on combat roles.", ${ }^{98}$

President George H. W. Bush created the Presidential Commission in April, 1992, which released its report on November 15, 1992.9 In summary, the Commission recommended women continue to be excluded from ground combat and air combat (and those exclusions be codified in law), but recommended combat ships be opened to women. ${ }^{100}$ The Commission came under a great deal of criticism for being politically charged. According to Vice Adm. William P. Lawrence, U.S. Navy (Ret.),

the White House disregarded the Secretary of Defense and Congress's nominations of several distinguished individuals of recognized competence, experience, and objectivity. Instead, appointed among the 15 commissioners were five arch-conservatives, who from the beginning of deliberations appeared determined not only to prevent expansion of women's roles in the military, but if possible to roll them back. ${ }^{101}$

Upon the release of the Commission's report, The Washington Post referred to the report as a "partisan mess," opining: "A new administration, which will take up the question of women in combat along with other military issues, would do best to ignore most of the report and start again."102

The new Clinton administration did just that, and on April 28, 1993, Secretary of Defense Les Aspin announced his decision to open all combat aviation assignments to women. He also directed the Navy to open more ship assignments and types of ships to women within current law and directed the

95. Id. at 470 (alteration added).

96. Pub. L. No. 102-190, 105 Stat. 1290 (1991).

97. 10 U.S.C. $\S 8549$ was rescinded entirely, and $\S 6015$ was amended to remove the combat aviation prohibition.

98. William P. Lawrence, Commission on Women in Combat, 119 U.S. NAVAL INST. PROC. 48 (Feb. 1993) [hereinafter Lawrence, Commission]. The requirement for the Commission was a tactic by conservatives in the Senate Armed Services Committee to table/stall a proposed amendment to open combat aviation to women. The amendment to repeal the combat aviation exclusion was reintroduced on the floor of the Senate and approved, but the commission requirement remained in the language of the bill. HOLM, supra note 43 , at 487-503.

99. PRESIDENTIAL COMMISSION REPORT, supra note 22.

100. See generally id.

101. Lawrence, Commission, supra note 98 , at 48 .

102. Id. at 51 . 


\section{WOMEN IN COMBAT: IS THE CURRENT POLICY OBSOLETE? 1027}

Navy to draft a legislative proposal to repeal the law that prohibited women from serving on ships engaged in combat missions. The Secretary also directed the Army to study opening additional jobs including air defense artillery and field artillery. Exceptions to the policy would "include units engaged in direct combat on the ground, assignments where physical requirements are prohibitive, and assignments where the costs of appropriate berthing and privacy arrangements are prohibitive..$^{\prime 103}$

On November 30, 1993, the President signed the 1994 Defense Authorization Act, ${ }^{104}$ which repealed the law ${ }^{105}$ prohibiting women from serving on combat ships. The new law also directed the Secretary of Defense to provide Congress with thirty-day notice when opening any additional assignments of women to "combat units, class of combat vessel, or type of combat platform."106 It also directed the Secretary of Defense to provide ninety-day notice to Congress on any changes to DoD's ground combat exclusion policies, including a detailed description, justification, and implications of proposed changes on the constitutionality of the male-only draft. Upon the passing of this Act, the United States no longer had any law restricting women from serving in any positions or units in the military. All restrictions were (and continue to be) a matter of DoD policy, albeit with Congressional reporting mechanisms and oversight.

On January 13, 1994, Secretary Aspin signed a policy memo to rescind the "risk rule" policy as a basis for barring assignment of women to some noncombat positions. In its place, he established the current ground combat exclusion policy, which loosened the direct ground combat definition. According to the Government Accounting Office (GAO), "[i]n DoD's view, the risk rule was no longer appropriate based on experiences in Operation DESERT STORM, where everyone in the theater of operation was at risk." ${ }^{107}$ On July 28, 1994, the newly appointed Secretary of Defense, William Perry, notified Congress that, as a result of the new ground combat exclusion policy and a thorough review of implementation by all services, 81,000 jobs previously closed to women would be opened by October $1,1994 .^{108}$

According to the GAO, in 1998, approximately 221,000 positions out of 1.4 million in the military were closed to women: 101,733 due to direct combat; 89,755 due to the collocation rule; 25,663 due to living arrangements, ${ }^{109}$ and 3935

103. Memorandum from Secretary of Defense Les Aspin to the Secretaries of the Army, Navy, and Air Force et al., Direct Ground Combat Definition and Assignment Rule (Jan. 13, 1994), reprinted in Assignment of Army and Marine Corps Women Under the New Definition of Ground Combat: Hearing Before Subcomm. on Mil. Forces \& Personnel of the H. Comm. on Armed Services, 103d Cong. 88-89 (1994).

104. Pub. L. No. 103-160, 107 Stat. 1547 (1993).

105. 10 U.S.C. $§ 6015$, repealed by Pub. L. 103-160, §541(a), 107 Stat. 1659 (1993).

106. Assignment of Army and Marine Corps Women Under the New Definition of Ground Combat: Hearing Before Subcomm. on Mil. Forces E Personnel of the H. Comm. on Armed Services, 103d Cong. 87 (1994) (reprinting excerpt from H.R. REP. No. 103-357 (1993) (Conf. Rep.)). See also 10 U.S.C. $\S 652(\mathrm{~b})(1)-(2)$ (West Supp. 2007).

107. GAO, GENDER ISSUES, supra note 5 , at 1 .

108. Assignment of Army and Marine Corps Women Under the New Definition of Ground Combat: Hearing Before Subcomm. on Mil. Forces \& Personnel of the H. Comm. on Armed Services, 103d Cong. 9798 (1994) (reprinting memorandum of William Perry, Secretary of Defense).

109. In this Article, the author is not analyzing the issue of excluding women from certain positions based on inadequate gender-separate living arrangements (like submarines), although it is 
due to Special Operations status. ${ }^{110}$ The GAO report also stated that the approved direct combat definition "may not account for anticipated changes in military operations" because it links the definition to a position "well forward on the battlefield" in a linear battle. ${ }^{111}$ The report concluded: "Ground combat experts in the Army and Marine Corps note that, in the post-Cold war era, the non-linear battlefield is becoming more common. Should this trend continue, defining direct ground combat as occurring 'well forward on the battlefield' may become increasingly less descriptive of actual battlefield conditions." ${ }^{\prime 12}$ Just a few years later, this prediction would become very apparent in Afghanistan and Iraq.

\section{ANALYSIS OF THE GROUND COMBAT EXCLUSION POLICY}

From Fort Washington in 1776 to Camp Victory in 2007, policy and law regarding women in combat roles shows a progressive march toward full integration based on capability, not gender. The nature of wars we fight today, as in Iraq and Afghanistan, has rendered untenable the DoD's definition of "direct combat." Nonetheless, the policy of exclusion remains. The common arguments against the exclusion revolve around this question: Why are women as an entire class restricted from assignment to ground combat units, support units that routinely collocate with them, and special operations units, even when many women are fully qualified and capable of service in these positions? $?^{113}$

Some of the common arguments underpinning the combat exclusion are based on opinions as to whether women could serve in positions that are currently closed to them, while others deal with whether they should. ${ }^{114}$ These arguments are founded on the premise that women and men should not be treated as individuals, but rather as a class with generalized characteristics. The most typical arguments against women in ground combat are: (1) women lack the physical strength to be effective in ground combat; (2) women's presence will decrease unit cohesion and therefore overall effectiveness; and (3) women just don't belong in combat.

her personal opinion that this should not be a reason to exclude all women from certain jobs. Of note, other nations have integrated women into these types of units.

110. GAO, GENDER ISSUES, supra note 5, at 5. The number of positions closed to women in 1998 should approximate the number of positions closed to women today because there have been no significant changes to policy or end strength. See E-mail from Cynthia Bingham, Joint Personnel Readiness Planner, JCS/J1, to Col. Robert Labrutta, USAF (Dec. 2006) (explaining that JCS/J1 does not track the number of positions closed to women and that the number of positions closed today should approximate the number closed in 1998 because there have been no significant changes to policy or end strength) (on file with author). For a list of positions closed to women as of 2005, as reported by the Defense Department Advisory Committee on Women in the Services (DACOWITS), see Appendix A.

111. GAO, GENDER ISSUES, supra note 5 , at 7 .

112. Id. at 10 (alteration added).

113. From this point on, when I discuss the "ground combat exclusion policy," I am including ground combat units, support units that collocate with them, and special operations units.

114. For examples of women in combat in other nations in the modern era, see Appendix $B$. 


\section{WOMEN IN COMBAT: IS THE CURRENT POLICY OBSOLETE? 1029}

\section{A. Physical Strength}

On average, men are stronger than women. As the 1992 Presidential Commission on the Assignment of Women in the Armed Forces stated,

[t]he evidence before the Commission clearly shows distinct physiological differences between men and women. Most women are shorter in stature, have less muscle mass, and weigh less than men. These physiological differences place women at a distinct disadvantage when performing tasks requiring a high level of muscular strength and aerobic capacity, such as hand-to-hand fighting, digging, carrying heavy loads, lifting, and other tasks central to ground combat. ${ }^{11}$

The Commission then admitted that it also heard testimony from women with tremendous physical ability who desired to serve in ground combat. ${ }^{116}$ Nonetheless, the Commission recommended excluding women from combat aircraft and ground combat, basing its recommendations partly on the issue of physical strength.

Closer inspection of the argument from "physical strength" reveals two troubling double standards. First, as discussed more fully below, the argument that women should be excluded from combat because they do not possess the requisite physical strength is both over- and under-inclusive; many women have the physical strength to engage in ground combat while many men do not. Second, the Army does not submit male recruits to physical strength examinations before assigning them to ground combat positions. ${ }^{117}$ Male recruits are assigned to combat (or non-combat) positions based on a combination of aptitude scores, medical evaluations, and personal preferences. ${ }^{118}$ While each Army job is assigned a physical demands rating, the rating is used only to give recruits an idea of the rigors of the job. ${ }^{119}$ A male recruit's physical strength is

115. PRESIDENTIAL COMMISSION REPORT, supra note 22, at 24.

116. Id.

117. Interview with Army recruiters at recruiting station in Montgomery, Ala. (Mar. 29, 2007); Interview with Army Military Entrance Processing Station (MEPS) staff in Montgomery, Ala. (Mar. 29, 2007). Each Army job, combat and non-combat, has specific entry requirements, outlined in Army Pamphlet 611-21. Dep't of the Army, Pamphlet 611-21, Military Occupational Classification and Structure (Jan. 27, 2007) [hereinafter Army Pamphlet 611-21]. Army recruiters administer the AFQT aptitude test, see infra Part I.D, and MEPS personnel assign the recruit to a job based on his or her test results, medical evaluation, and personal preference. As in the Air Force, each Army recruit must pass a basic physical fitness test to enter the Army and a yearly physical fitness test. These tests are age- and gender-normed and are intended to ensure a minimum standard of health for all military personnel; the tests do not assess eligibility for specific positions. Yet the gender-norming of this test is cited as an example of a double standard by critics of women in the military, who apparently misunderstand (or misrepresent) the purpose of the test and conveniently omit the agenorming when articulating their argument. See, e.g., Lee Bockhorn, Woman at Arms, 102 POL'Y REV. (Hoover Inst.) (Aug.-Sept. 2000) (reviewing STEPHANIE GuTMANN, THE KindER, GENTLER MiLITARY: CAN AMERICA'S GENDER-NEUTRAL FIGHTING FORCE STILL WIN WARS? (2000)), available at http://www.hoover.org/publications/policyreview/3487422.html.

118. Interview with Army MEPS staff, supra note 117.

119. Id. There are five physical demand categories: Light, Medium, Moderately Heavy, Heavy, and Very Heavy. Light demand is described as, "[l]ift on an occasional basis a maximum of $20 \mathrm{lbs}$ with frequent or constant lifting of 10 pounds;" very heavy demand is described as, "lift on an occasional basis over 100 pounds with frequent or constant lifting in excess of 50 pounds." See Army 
tested only informally by whether he can complete the training required for the combat job. ${ }^{120}$ The double standard here is glaring: Male recruits are not disqualified from entering combat career fields for lack of physical strength, but all female recruits are peremptorily disqualified from such fields regardless of their physical strength.

As a female who has both engaged in combat and led others into combat, it is my view that women should not be restricted, due to gender-based generalizations about physical strength, from any assignments for which they are physically qualified. My opinion is based on the following:

1. Military effectiveness requires that we pick the best qualified person for the job, regardless of gender.

While many men possess the physical strength and stamina to be in "ground combat" positions, many other men do not. Men should not be deemed qualified for physical demands of combat positions on the basis of their gender and women who possess the requisite physical strength and stamina should not be excluded from combat assignments on the basis of their gender. Instead, eligibility should turn on whether the recruit-male or female-meets the physical qualifications for the job. Again, physical qualification is currently based on whether the recruit can complete the initial training for the assigned specialty. ${ }^{121}$

A gender-neutral policy will allow the most capable force to be assembled. All potential recruits should be screened as individuals, rather than by eliminating one group of potential recruits solely on the basis of a stereotype or generalization. Military effectiveness, and not gender, should be the sole criteria for assignment policies.

2. This argument was used to keep women out of fighter aircraft in the early 1990 s and proved to be wrong.

During the debate on whether women should or could be fighter pilots, many people used the "physical strength" argument to advocate the continued prohibition on women. Five members the Presidential Commission made this argument in the Alternative Views section of the Commission's report. ${ }^{122}$ They

Pamphlet 611-21, supra note 117, at ch. 9, II 5.b. (alteration added). This categorization applies to all Army jobs, combat and non-combat. Some non-combat jobs that women can currently fill have physical demand ratings of Very Heavy-e.g., 45B-Small arms/Artillery Repairer-while other combat jobs closed to women have the lower rating of moderately heavy-e.g., 13M-Multiple Launch Rocket System Crewmember. See id. at ch. 10, III 10-141, 10-55.

120. Interview with Army MEPS staff, supra note 117. Some Air Force combat jobs, such as pararescue and combat control, require a male recruit to pass a unique physical fitness test upon entry. See Air Force Instruction 36-2626, Airmen Retraining Program, attach. 11 (July 1 1999), available at http://www.e-publishing.af.mil/pubfiles/af/36/afi36-2626/afi36-2626.pdf.

121. According to Montgomery, Ala., Army MEPS staff, no male Army recruit is sent to a combat position against their will. If the combat exclusion were lifted, women (and men) who qualified for combat jobs will also have a choice to serve in non-combat positions for which they are qualified. See Interview with Army MEPS staff, supra note 117.

122. See PRESIDENTIAL COMMISSION RePORT, supra note 22, at 43-79. The five Commissioners were Samuel Cockerham, Elaine Donnelly, Sarah White, Kate Walsh O'Beirne, and Ronald Ray. See id. 


\section{WOMEN IN COMBAT: IS THE CURRENT POLICY OBSOLETE? 1031}

quoted many experienced male fighter pilots who discussed the physical strength and stamina required to be a combat fighter pilot and how women had yet to prove they were physically capable of the rigors of aerial combat. For example, when asked about women who were already flying F-18s in the Navy as test pilots and instructors, one Navy Top Gun instructor pilot stated:

[Y]es, we do have women flying F-18s today, and that is a fact. They are currently not flying the F-18s that any of us have flown in the fleet or out in the combat missions. To compare the missions that they are doing today to what we are doing is like comparing driving the L.A. Freeway to driving the Indianapolis 500. It's just not the same. ${ }^{123}$

The Commissioners with alternative views also quoted Lt. Gen. Buster Glossen, USAF, (who was responsible for air campaign strategy and execution in DESERT STORM) extensively on the stamina, which he defined as strength and endurance, needed to be a fighter pilot. He described the strength and endurance that fighter pilots need to sustain high G-forces without losing consciousness as well as to fly seven to nine hour grueling combat missions on a daily basis and said "the jury is still out" on whether women have the requisite stamina. ${ }^{124}$

It does take a great deal of strength and endurance to be a fighter pilot. But notwithstanding the Commission's and Glossen's doubts, at least forty-nine women in the active-duty Air Force have completed fighter pilot training successfully and most, including the author, have flown long, demanding combat missions for Operations SOUTHERN WATCH, NORTHERN WATCH, DESERT FOX, ALLIED FORCE, ENDURING FREEDOM, or IRAQI FREEDOM. Air Force women fighter pilots have earned sixteen Distinguished Flying Crosses in Iraq and Afghanistan since $2001 .{ }^{125}$ Critics who claimed that women do not have the strength and stamina to be fighter pilots in combat have been proven wrong by women's actual performance. Some, like Elaine Donnelly, were eventually forced to concede that women fighter pilots "seem to be serving very well" and "appear to be competent and well qualified, and by all accounts are doing well." ${ }^{126}$ Despite this positive experience with female fighter pilots, critics continue to use arguments based on physical strength and stamina as justifications for keeping the current combat exclusions in place.

123. Id. at 68

124. Id. at 67. This issue has particular personal significance for the author. When combat aviation was opened to women in 1993, I was training to represent the USAF at the Hawaii Ironman World Triathlon Championship, a grueling athletic event consisting of a 2.4-mile swim, 112-mile bike ride, and 26.2-mile run. It is one of the ultimate physical tests of strength, endurance, and mental toughness. Each military service picked its best athletes for the competition. I easily won the women's military division and beat all but just a handful of the men in all four branches of the service. Yet, some were still arguing that, as a class, women did not have the physical strength or endurance to be fighter pilots.

125. E-mail from United States Central Command Air Forces Director of Manpower and Personnel (CENTAF/A1) Colonel David Zeh to the author (Jan. 3, 2007) (on file with the author).

126. Lisa Hoffman, Women in the military no longer remarkable, SCRIPPS HOWARD NEWS SERV. (online ed.), Jan. 11, 2002, http:/ /www.ctie.monash.edu.au/hargrave/further_reading_USA.html. 
3. All relevant qualities should be considered.

All personnel wearing the uniform must have some basic level of physical strength to ensure they can defend themselves in battle. However, a capable combat soldier must possess more than just physical strength. Skill, motivation, and a fighting spirit are just as crucial for the warrior, and all of these characteristics are gender-blind. Army and Marine leadership have recently been emphasizing additional crucial traits like judgment, discipline, restraint, and intellect, to name a few. Former Marine Corps Commandant General Charles Krulak has spoken and written about the "strategic corporal" who has to be ready to fight a three-block war. On any given day, in any contingency, that corporal may be dealing with hostile acts on one block, intervening to prevent conflict on another block, and providing humanitarian assistance on the third block:

The inescapable lesson of Somalia and of other recent operations, whether humanitarian assistance, peace-keeping, or traditional warfighting, is that their outcome may hinge on the decisions made by small unit leaders, and by actions taken at the lowest level. The Corps is, by design, a relatively young force. Success or failure will rest, increasingly, with the rifleman and with his ability to make the right decision at the right time at the point of contact... [T] oday's Marines will often operate far "from the flagpole" without the direct supervision of senior leadership.... [T] hey will be asked to deal with a bewildering array of challenges and threats. In order to succeed under such demanding conditions, they will require unwavering maturity, judgment, and strength of character. Most importantly, these missions will require them to confidently make well-reasoned and independent decisions under extreme stress-decisions that will likely be subject to harsh scrutiny of both the media and the court of public opinion. ${ }^{127}$

Warriors must be strong, but they must also possess these other vital qualities that are more likely to affect the strategic outcome. In 2005, the Secretary of Defense commissioned the RAND Corporation (a non-profit research group) to study various factors that determine military performance. The study primarily investigated experience, training, and aptitude. It is interesting to note that the RAND study did not even include physical strength as a relevant factor in measuring military aptitude. ${ }^{128}$ The study found overwhelming evidence that aptitude (as measured by AFQT scores) was a crucial factor in determining effectiveness in combat forces. For example, replacing a tank gunner who had a Category IV AFQT score with one who was Category IIIA ${ }^{129}$ improved the chances of hitting their targets by thirty-four percent. ${ }^{130}$ The Army almost doubled the number of Category IV recruits in 2006. Women recruits are generally brighter than their male counterparts and they

127. Charles C. Krulak, The Strategic Corporal, Leadership in the Three Block War, MARINES MAG., Jan. 1999, at 236-37 (emphasis in original; alterations added).

128. Jennifer KaVAnagh, Determinants of Productivity For Military PersonNel: A RevieW of Findings on the CONTRIbUtion of Experience, Training, and Aptitude to Military PERFORMANCE 27 (2005).

129. For a description of aptitude scores and categories, see Part I.D, supra.

130. Kavanagh, supra note 128 , at 27. 
have fewer disciplinary problems. ${ }^{131}$ In order to get the best team of ground combat warriors based on physical strength and all other relevant qualifications, it is not logical to include marginally qualified CAT-IV males while excluding physically qualified CAT-I-III females.

\section{The author's personal experience}

When Congress repealed the law that excluded women from flying in combat, I was in the middle of undergraduate pilot training. The Air Force had a merit-based rating system for men and women throughout the one-year program. All pilots received grades on every test, simulator, flying maneuver, and commander assessment. Prior to choosing assignments, pilots were ranked based on gender-blind performance. Based on my performance, I thought I was going to have the opportunity to become a fighter pilot.

The massive military drawdown of 1990 and 1991 limited the availability of flying assignments, particularly fighter assignments. Consequently, upon graduation, approximately fifty-five percent of my class was assigned to nonflying support jobs for three years. Only one pilot was assigned to a fighter aircraft. After three years, pilots who were delayed went on to train in a specific aircraft based on their performance, preference, and aircraft availability. I graduated fifth in my class and requested a delayed fighter assignment-an assignment that would have been available to me if I were a man. Because the DoD policy had not yet changed, my request was denied. I then chose an assignment as a T-37 Instructor Pilot in order to keep my options open for a future fighter assignment, if and when the policy changed. Males in my class who were ranked below me were able to choose delayed fighter assignments.

As a T-37 Instructor Pilot, I witnessed several classes of pilots graduate with a woman ranked at or near the top of the class. Yet again, the lower-ranked male pilots went on to become fighter pilots, and the better performing females could not, solely on the basis of their gender. This type of exclusionary policy does not result in the most capable fighting force.

After I became a fully qualified, combat-ready A-10 pilot, I discovered there was a policy that still limited me from fulfilling all the responsibilities of my job. Prior to 2005, all A-10 squadrons were responsible for providing battalion air liaison officers (BALOs) to specific Army ground combat battalions. BALOs are trained to provide advice and coordination on integration of air power for the battalion. They also control air strikes to support ground forces by talking to the pilots on the radio. These pilots train and deploy on the ground with their assigned units when called, and many A-10 pilots served in this capacity on the ground in DESERT STORM and IRAQI FREEDOM. In order to

131. Lawrence Korb stated,

"In my view, women actually increase readiness, since they have more education and higher aptitudes than their male counterparts. But we hear a lot of anecdotes about women tending to be absent from duty for medical reasons more frequently than men. These anecdotes, though, overlook the fact that men are frequently absent for more 'traditional' reasons-being drunk and disorderly, for example . . .."

Sheila Nataraj Kirby \& Harry J. Thie, Enlisted Personnel Management: A Historical Perspective 96-97 (RAND Corp. 1996) (quoting Lawrence Korb, Asst. Sec'y of Def. for Manpower, Reserve Affairs, \& Logistics, 1981-85). 
qualify as a BALO, a pilot has to attend a three-week training program, pass a physical-fitness test, and go through a local certification program, which includes controlling live air strikes. I earned distinguished graduate status at the school, aced the gender-blind physical fitness test, and became certified as a BALO. However, due to my gender and the collocation policy, I was prohibited from being assigned to an Army unit.

Given my qualifications and skills, this policy made no sense as applied to me. I sent an initiative up the chain of command to ask for an exception to policy. The Chief of Staff of the Air Force approved and received agreement from the Assistant Secretary of the Army for Manpower and Reserve Affairs for me to deploy to an exercise as a "test case" BALO. On the eve of the exercise in 1997, the initiative was postponed. The e-mail forwarded to me stated: "this initiative will happen,--probably sooner than later. But, as I [549 Combat Training Squadron Commander (549 CTS/CC)] told you [355 Operations Group Commander ( $355 \mathrm{OG} / \mathrm{CC}$ ], I don't think the timing is right." ${ }^{\prime 132}$ The initiative never happened. In 2005, the Air Force decided that A-10 pilots would no longer have to serve in BALO positions. Instead, enlisted specialists who are not pilots would become BALOs. Women are still prohibited from serving in this role based on the collocation policy.

\section{B. Cohesion}

Those who advocate restricting women from "ground combat" dismiss the argument that combat effectiveness is enhanced by having all members of the force eligible for all positions. As stated in the Alternative Views section of the Presidential Commission report: "The key question in preparing to win and survive in combat is not what is best for the individual but what is best for the unit and the military as a whole. This is why the Commission spent considerable time seeking and evaluating testimony and studies on unit cohesion. ${ }^{\prime 133}$ As a concept that relates to the quality of relations between individuals, as opposed to characteristics of an individual, cohesion is more difficult to measure empirically and is therefore less subject to objective assessment.

Cohesion is a complex term that describes the unity and bonding that a unit must possess in order to be a team in battle. There are two general types of cohesion: social cohesion and task cohesion:

Social Cohesion refers to the nature and quality of the emotional bonds of friendship, liking, caring, and closeness among group members. A group is socially cohesive to the extent that its members like each other, prefer to spend their social time together, enjoy each other's company, and feel emotionally close to one another.

132. E-mail from 549 CTS/CC to 355 OG/CC (Jan. 16, 1997) (on file with the author). This e-mail was from the squadron commander responsible for coordinating the Air Force support to the Army exercise and was sent to the Operations Group Commander at Davis Monthan Air Force Base (my group commander). The e-mail explained that the exercise we picked for my test case deployment was high visibility for the Army to test future technology and tactics and not ideal for an experiment with female BALOs.

133. PRESIDENTIAL COMMISSION REPORT, supra note 22, at 44 . 


\section{WOMEN IN COMBAT: IS THE CURRENT POLICY OBSOLETE? 1035}

Task Cohesion refers to the shared commitment among members to achieving a goal that requires the collective efforts of the group. A group with high task cohesion is composed of members who share a common goal and who are motivated to coordinate their efforts as a team to achieve their goal. ${ }^{134}$

While focusing a great deal on cohesion as a reason to exclude women from combat, the 1992 Presidential Commission admitted that " $\mathrm{t}]$ here are no authoritative military studies of mixed-gender ground combat cohesion, since available cohesion research has been conducted among male-only ground combat units." ${ }^{135}$ To fill the void of data, they resorted to interviewing many men who never had women in their units - a rather biased sample-to get their opinions on how women would affect cohesion. Similar techniques were used in the past to keep African-Americans from serving in racially integrated units. For example, in 1925 the Army War College published a study claiming that close association of Blacks and Whites in military organizations was detrimental to harmony and efficiency and that Blacks were inherently more cowardly than Whites. ${ }^{136}$ Experience has long since shown these claims to be completely false. With military readiness at stake, we should not let prejudicial racist or sexist attitudes drive our policies. Women, by their presence alone, simply do not impede cohesion from happening for a variety of reasons:

1. Military cohesion is based on people uniting for a common mission or purpose, not based on the group consisting of a common race, creed, or gender.

Studies have also shown that it is task cohesion that is essential to getting the job done, though there is some debate whether task cohesion begets mission effectiveness or an effective mission begets task cohesion: ${ }^{137}$ "Task cohesion has a modest but reliable influence on performance; social cohesion does not have an independent effect after controlling for task cohesion. Under some conditions, high social cohesion is actually detrimental to unit performance; moderate social cohesion appears most beneficial. "138

In 1997, RAND analysts Margaret Harrell and Laura Miller conducted a study on the expansion of women's roles in the military following law and policy changes in the early 1990s and the effect on cohesion, readiness, and morale. The study focused on units that opened new positions to women after the 1993-94 policy changes. When asked to provide written comments about the factors that determined their unit's level of cohesion, only ten out of 619 survey respondents even mentioned gender, despite the survey cover and introduction

134. Laura L. Miller \& John Allen Williams, Do Military Policies on Gender and Sexuality Undermine Combat Effectiveness?, in SOlDIERS AND CIVILIANS: THE CIVIL-MILITARY GAP AND AMERICAN NATIONAL SECURITY 361, 389 (Peter D. Feaver \& Richard H. Kohn eds., 2001) (quoting Robert MacCoun, What is Known About Unit Cohesion and Military Performance, in SEXUAL ORIENTATION AND U.S. MilitARy PERSONNEl POLICY: OPTIONS AND ASSESSMENT 291 (1993)).

135. PRESIDENTIAL COMMISSION REPORT, supra note 22, at 25.

136. Lt. Col. Henderson BaKer, II, WOMEn in Combat: A Culture Issue? 6 (U.S. Army War Coll. 2006), available at http:/ / www.strategicstudiesinstitute.army.mil/pdffiles/ksil271.pdf.

137. David R. Segal \& Meyer Kestnbaum, Professional Closure in the Military Labor Market: A Critique of Pure Cohesion, in THE FUTURE OF THE ARMY PROFESSION 441-58 (Don M. Snider \& Gale L. Watkins eds., 2002).

138. Miller \& Williams, supra note 134 , at 54 . 
explaining that gender was an important component of the study. ${ }^{139}$ The RAND authors concluded that "[any] divisions caused by gender were minimal or invisible in units with high cohesion. Gender was reported as a secondary issue in units that had conflicting groups, and then it took a back seat to divisions along work groups or rank lines."140 Some respondents stated that women increase unit cohesion: "Where people mentioned a positive effect of gender integration on cohesion, it was to comment that women's presence had raised the professional standards of conduct in the military workplace."141

In 1999, the GAO conducted a report on perceptions of readiness in selected units. The report concluded: "Our survey on the perception of readiness of units opened to women since 1993 showed that both men and women had a positive view of their own readiness. Furthermore, most men and women agreed that women either affected readiness no differently from men or affected readiness positively or very positively. ${ }^{\prime 142}$ The RAND and GAO studies provide strong evidence that the presence of women in these combat units either increased or did not decrease their task cohesion, casting strong doubts on the unsubstantiated claims of critics.

\section{Cohesion is a leadership issue.}

The Presidential Commission concluded that women's presence might impede cohesion in ground combat units due to lack of ability to do the job, lack of privacy, traditional male views of women, sexual misconduct, and pregnancy. Cohesion between all males might also be impeded by a number of other elements-i.e., an individual's lack of ability to do his job or carry his weight, selfishness, racist attitudes, lack of integrity, favoritism, or a variety of other dynamics that could degrade the team. However, none of these elements are inevitable and the right leadership climate can identify and eliminate the primary causes of degraded cohesion: double standards and behavior that "degrades the good order and discipline in the armed forces." ${ }^{143}$ The reality is that there are challenges in bringing a group of any human beings-male or

139. Margaret C. Harrell \& Laura L. Miller, NeW Opportunities for Military Women: EFFECTS UPON READINESS, COHESION AND MORALE 57 (1997).

140. RAND Research Brief, Military Readiness: Women are Not a Problem 3 (1997) (alteration added), available at http://www.rand.org/pubs/research_briefs/RB7515/index1.html. It is interesting to note that Elaine Donnelly dismisses the RAND study as censored by the Pentagon. On her website for the Center for Military Readiness, she makes the following claims: the report was "revised and 'cleansed' of political incorrectness ... unidentified spinmeisters exorcised sensitive passages .... Congress should investigate Pentagon censorship ...." Center for Military Readiness, CMR Analyzes 1997 Rand Study (Mar. 1, 2006) http://www.cmrlink.org/WomenInCombat.asp? docID=263 (last visited Mar. 2, 2007).

141. Harrell \& Miller, supra note 139, at 66-67.

142. Gen. Accounting Office, Gender Issues: Perceptions of ReAdiness in Selected Units 5 (1999), available at http:/ / www.gao.gov/archive/1999/ns99120.pdf.

143. The next few paragraphs discuss all of the cohesion issues raised by the Commission except privacy issues and traditional male views of women. Privacy concerns can be ameliorated by providing some segregation in sleeping quarters or, if not practical in combat conditions, discretion and respect among professional adults as they focus on the mission, get rest, and attend to personal hygiene. Prejudiced attitudes toward women need to be identified, confronted, and altered, just as they were during racial integration of the military. 


\section{WOMEN IN COMBAT: IS THE CURRENT POLICY OBSOLETE? 1037}

female-together to form a cohesive and effective team. Add in the stresses of combat training and life-threatening situations and the challenges increase. Unit leadership must create a climate where every person is respected as a team member with equal opportunity, responsibility and accountability.

Double standards of performance should not be tolerated for any subset of service members. ${ }^{144}$ Some formal double standards that the author believes do degrade unit cohesion are: gender-segregated basic training, separate standards for men and women in basic training, lack of uniformity in military uniforms, policies that demean or degrade servicewomen, and women's exemption from selective service registration. Additionally, poorly timed pregnancies can create the perception or reality of a double standard and decrease readiness and therefore cohesion and morale in a unit. ${ }^{145}$ All of these issues are discussed in greater detail in Part IV, infra.

The remaining causes of decreased cohesion generally fall into the category of behavior that the military calls "prejudicial to good order and discipline." This term is derived from Article 134 of the Uniform Code of Military Justice (UCMJ), which is used by commanders to punish a variety of offenses. Article 134 provides:

Though not specifically mentioned in this chapter, all disorders and neglects to the prejudice of good order and discipline in the armed forces, all conduct of a nature to bring discredit upon the armed forces, and crimes and offenses not capital, of which persons subject to this chapter may be guilty, shall be taken cognizance of by a general, special, or summary court martial, according to the nature and degree of the offense, and shall be punished at the discretion of that court. $^{146}$

Article 134 is a "catch all" article for behavior that is not listed in other UCMJ articles, but clearly degrades the team or discredits the military.

Of all the possible behaviors that degrade the good order and discipline of the armed forces, sexual misconduct is an offense that might uniquely arise from gender integration. Sexual misconduct can come in the form of sexual assault as well as consensual sexual relationships that degrade good order and discipline. With regard to the latter, a gender-integrated unit might deal with three possible scenarios: (1) sexual relationships where one partner is married; (2) sexual relationships where one partner is superior in rank or position; and (3) sexual relationships between single service members of similar rank.

If one member is married, this is considered adultery and is punishable under Article 134, UCMJ ${ }^{147}$ If one member is a superior in rank, this behavior is prohibited by service regulations. Air Force Instruction 36-2909, Professional and Unprofessional Relationships, provides:

Dating, courtship, and close friendships between men and women are subject to the same policy considerations as are other relationships. Like any personal

144. See infra Part IV.B.

145. See infra Part IV.A.

146. 10 U.S.C. § 934 (2000) (codifying Article 134, UCMJ).

147. Id. See also MANUAL FOR COURTS-MARTIAL, United StATES, Pt. IV, Art. 134, IIII 60-113 (2005) [hereinafter MCM], available at http:/ / www.au.af.mil/au/awc/awcgate/law/mcm.pdf. 
relationship, they become matters of official concern when they adversely affect morale, discipline, unit cohesion, respect for authority, or mission accomplishment. Members must recognize that these relationships can adversely affect morale and discipline, even when the members are not in the same chain of command or unit. The formation of such relationships between superiors and subordinates within the same chain of command or supervision is prohibited because such relationships invariably raise the perception of favoritism or misuse of position and erode morale, discipline and unit cohesion. $^{148}$

The final scenario is a sexual relationship between single service members of equal rank. Unit leadership must create a climate where individuals respect one another and understand that, unlike in the civilian context, their personal life choices can negatively impact the good order and discipline of a military unit. Commanders then must deal with each individual case, just as they must deal with a plethora of other personal choices that might negatively affect their team. Harrell and Miller discovered that gender issues were cited by fewer than one percent of their respondents when asked about issues that affect morale in recently gender-integrated units. However, they concluded that, "when they occur, dating and sexual relationships, even when not proscribed by the regulations, are often problematic within military units. ${ }^{\prime 199}$

AFI 36-2909 captures all unprofessional relationships that degrade good order and discipline-whether between individuals of the same gender or opposite sex.

Relationships are unprofessional, whether pursued on or off-duty, when they detract from the authority of superiors or result in, or reasonably create the appearance of, favoritism, misuse of office or position, or the abandonment of organizational goals for personal interests." Unprofessional relationships can exist between officers, between enlisted members, between officers and enlisted members, and between military personnel and civilian employees or contractor personnel. Fraternization is one form of unprofessional relationship and is punishable under Article 134 of the Uniform Code of Military Justice (UCMJ). ${ }^{150}$

Leadership is vital to ensuring that no relationships-sexual or nonsexualdecrease good order and discipline and mission effectiveness.

With regard to sexual assault, if the U.S. military has a sexual predator in the ranks, he or she should be identified, punished, and removed from the team. Restricting female soldiers from combat units will not protect all women in uniform from male sexual predators. Male sexual predators will come in contact with other women - combat support personnel, enemy, and innocent civilianswho may be victimized. We have seen the strategic consequences of male soldiers raping innocent civilians. U.S.-Japanese relations were severely strained in 1995 after three Marines raped a twelve-year-old Okinawan girl. In December

148. Dep't of the Air Force, Air Force Instruction (AFI) 36-2909, Professional and Unprofessional Relationships (May 1, 1999) [hereinafter AFI 36-2909], available at http:/ /www.e-publishing.af.mil/ pubfiles/af/36/afi36-2909/afi36-2909.pdf.

149. Harrell \& Miller, supra note 139 , at 83.

150. AFI 36-2909, supra note 148. See also 10 U.S.C. $§ 934$ (2000) (codifying Article 134, UCMJ); MCM, supra note 147, at Pt. IV, Art. 134, II 83.b.(2), (4). 


\section{WOMEN IN COMBAT: IS THE CURRENT POLICY OBSOLETE? 1039}

2006, the U.S. cancelled a joint military exercise with the Philippines, and antiU.S. sentiments were stirred, over the custody dispute of a Marine convicted of raping a Filipino woman. ${ }^{151}$ The military must proactively address the issue of sexual assault in mixed-gender units and swiftly remove and punish men and women who commit such crimes. ${ }^{152}$ Blame must be placed appropriately: The assaulter is the one who degraded cohesion of the team, not the victim.

In sum, cohesion is a leadership issue, and leadership has the greatest effect on unit cohesion regardless of the gender composition of the team. It takes leadership to mold any group of disparate human beings into an effective combat unit focused on a mission where sacrifices must be made, trust must be built, and personal qualities of duty, responsibility, integrity, and discipline are essential.

3. This argument was used to keep all women out of fighter aircraft in the early 1990 s and was proven wrong.

The Presidential Commission heard testimony from many fighter pilots about how they were certain that the presence of women in fighter aviation would decrease cohesion and military effectiveness. The testimony of one Top Gun instructor pilot represents the opinions of twenty-one of the twenty-three pilots in his unit:

[T] he lieutenants out there, and the captains in the Marine Corps are screaming that 'No, we don't want this to happen.' And one big reason for it is that we need to have those units act as units. When you are out there in your fleet squadron, it is very important that you act as one, and you believe and share your experiences with each and every member, and you expect a lot out of that person, and you have to act as a unit. And if you can't do that-and we don't believe you can act as a unit unless you keep it the way it is, where it's the bonding-it's that intangible, the bonding that makes a squadron good, better, and we don't believe you can have that go on if we have females in aviation. ${ }^{153}$

Commissioner Elaine Donnelly summarized her views: "[M]ost combat aviators were opposed to the assignment of women to air combat units, primarily because of their concerns about the potential effects on unit cohesion which might decrease mission effectiveness and risk lives." ${ }^{154}$ Despite such views, the record has since shown that women have successfully integrated into combat aviation units and flown as teams in combat. The predictions of dire consequences and mission ineffectiveness have not panned out.

151. Associated Press, War Games Canceled Over Rape Case, Dec. 22, 2006, available at http://www.military.com/NewsContent/0,13319,121145,00.html; Associated Press, U.S. Servicemen Convicted in Okinawa Rape, Mar. 7, 1996, available at http://www.cnn.com/WORLD/9603/ okinawa_rape/.

152. Those found to have made false accusations of sexual assault must also be punished in order to ensure no degradation to unit cohesion and effectiveness.

153. PRESIDENTIAL COMMISSION REPORT, supra note 22, at 71.

154. Id. at 101 . 


\section{The author's personal experience}

As the first woman assigned to my combat A-10 squadron in 1994, I realized there were some concerns about a woman's integration into the unit. I knew that I needed to show my competency and capability. I performed very well in my combat-ready checkout program and won a squadron bombing competition despite being the least experienced pilot in the squadron. I earned respect as a fighter pilot, where performance is the ultimate, impersonal, gender-neutral standard. Within sixty days of my arrival in the squadron, we deployed to Kuwait for Operation SOUTHERN WATCH. Pilots were lodged in an area separate from the other troops. I worked with my commander to ensure I stayed in pilot lodging with my teammates. I lived in a trailer with four male pilots (in my own small room), and we shared a small bathroom with a shower. We maintained appropriate boundaries, exercised discretion, and fostered an atmosphere of respect for personal privacy. During that deployment, my unit became a cohesive team based on our combat mission focus, and my gender was simply not an issue.

Years later, when I took over command of that same squadron, I led a united, capable, and cohesive warfighting team. This cohesion was strengthened as we deployed to combat in Afghanistan for five months. As a united team dedicated to the mission, my squadron was awarded the prestigious Air Force Association David C. Shilling Award for the best aerospace contribution to national defense in 2005. I have personally experienced combat cohesion that was race-, religion-, and gender-neutral. In my almost nineteen years in uniform, I have also witnessed units with very weak cohesion for a variety of reasons. Poor leadership and non-gender-related favoritism generally characterized the units I observed with the lowest morale and cohesion. Cohesion is a leadership issue, not a gender issue.

So far, I have analyzed the issue of whether women could serve in ground combat, concluding that women should be assessed for assignment as individuals, not as a class. Some women are capable and some women are not, just as some men are capable and some men are not. ${ }^{155}$ Individuals should be evaluated for their capabilities, and leadership should set the conditions for cohesion between qualified individuals on the team. Leadership must also discipline or remove those whose behavior or attitudes, regardless of gender, detract from the team and decrease unit effectiveness. I now turn to the issue of whether women should serve in combat.

155. As a final data point, Canada removed all gender restrictions in its military in 1989 . According to the Canadian Forces Desk Officer for Gender Integration, women now make up 3.8\% of the ground combat arm officers and $1.4 \%$ of combat arms enlisted force. Women constitute nine percent of the deployed combat force in Afghanistan, including a female Master Corporal currently deployed as a rifle section second in command. Canada suffered its first female combat casualty in Afghanistan in 2006. The Captain was an armor officer. Canada has a gender-neutral performance standard for all of its positions. Total attrition rates for men and women in the last five years across the Canadian Forces were equal, at 6.2\%. E-mail from Lt. Cmdr. Gord AuCoin, Canadian Forces Desk Officer for Gender Integration to author (Dec. 22, 2006) (on file with author). For other examples of women in combat in other countries and in history, see Appendix B. 


\section{Women Just Don't "Belong" In Combat}

Some critics of women in combat center their arguments on personal beliefs regarding the "proper" roles of men and women. These critics argue that women must be givers and protectors of life-not takers of life-and that a man's role is to protect and a woman's role is to be protected. In the Presidential Commission's Alternative Views section, Elaine Donnelly and others stated: "Good men respect and defend women. Women should not be required, as the price of equality, to sacrifice this fundamental principle that governs a civilized order." ${ }^{\prime 156}$ The Presbyterian Church of America published a report in 2001 that used biblical references to conclude that all men have the God-directed duty to protect women (the "weaker" gender) and that women should not serve in combat. ${ }^{157}$ This report was signed by Bentley Rayburn, USAF (Ret.), in his capacity as a civilian; at the time, he was an active-duty general responsible for developing USAF senior leaders as the Air War College Commandant. ${ }^{158}$

Indeed, until the early 1990s, the U.S. government attempted to shield women (at least formally) from the risks of direct combat. When the nature of modern warfare began to blur the line between combat and non-combat, the government accepted the notion of placing women at risk in a combat zone; however, policymakers continued to prohibit women from serving as offensive combatants. As a result, the status quo is an emotionally charged line: Women can serve in defensive positions and fight back when attacked, but they cannot serve in offensive positions where they are required to seek out and kill the enemy.

Although attitudes regarding the "proper" role of women were overcome in the context of combat aviation, they continue to serve as the foundation for arguments by those who favor the ground combat exclusion policy. Additionally, these critics argue that America is not ready to handle seeing women in body bags or women as POWs. ${ }^{159}$ Are these accurate assessments of America's views on women in combat?

\section{Polls}

Since the early 1990s, many credible national polls conducted on the subject has found that a majority of Americans support giving women the option to serve in direct ground combat. In January 1990, in the aftermath of the invasion of Panama, a CBS News/New York Times poll of 1557 American adults found that seventy-two percent of those surveyed thought that military women should be allowed to serve in combat units on a voluntary basis. ${ }^{160}$ In 1992, the Presidential Commission hired the Roper Organization to conduct two polls: (1) a random telephone survey of 1700 American adults; and (2) a written survey of 4422

156. PRESIDENTIAL COMMISSION REPORT, supra note 22, at 61.

157. Ad Interim Study Committee on Women in the Military, General Assembly Actions and Position Papers of the Presbyterian Church in America, http://www.pcahistory.org/pca/1-278.html (last visited Nov. 29, 2006).

158. Id.

159. See, e.g., Kate O’Beirne, A New Horror of War, NAT'L REV., Apr. 21, 2003, at 24-26.

160. SKAINE, supra note 70 , at 121. 
active and reserve military personnel. The results of the Roper polls are reproduced in Table $1 .{ }^{161}$

The Roper poll found that the American public was supportive of women in combat: forty-five percent of those surveyed thought that women should be allowed to serve in ground combat, and an additional twenty-five percent thought that women should be required to serve in ground combat. ${ }^{162}$ Both the public and the military generally supported women serving in combat, but the military was evenly split on the issue of women serving in ground combat. Additionally, seventy percent of the public and fifty-seven percent of the military thought that the effect of women in combat would be positive or neutral. ${ }^{163}$

\begin{tabular}{|c|c|c|c|}
\hline \multicolumn{4}{|c|}{$\begin{array}{c}\text { TABLE 1. 1992 ROPER POLL CONCERNING THE ASSIGNMENT OF WOMEN TO } \\
\text { DIFFERENT TYPES OF COMBAT SITUATIONS }\end{array}$} \\
\hline TYPE OF AsSIGNMENT & NOT ASSIGN & VOLUNTARY & REQUIRE \\
\hline Assign to Combat Ships? & & & \\
\hline Public & $17 \%$ & $51 \%$ & $29 \%$ \\
\hline Military & $29 \%$ & $39 \%$ & $30 \%$ \\
\hline Assign to Combat Aircraft? & & & \\
\hline Public & $18 \%$ & $53 \%$ & $25 \%$ \\
\hline Military & $30 \%$ & $43 \%$ & $25 \%$ \\
\hline Assign to Ground Combat? & & & \\
\hline Public & $27 \%$ & $45 \%$ & $25 \%$ \\
\hline Military & $49 \%$ & $30 \%$ & $19 \%$ \\
\hline
\end{tabular}

In 1997, TIME Magazine conducted a telephone poll and reported that "a majority of those polled, sixty-seven percent, supported the statement that women should be allowed to serve in combat roles."164 The Triangle Institute for Security Studies conducted a 1998-99 Survey on the Military in the post-Cold War era. When asked if women should be allowed to serve in all combat jobs, fifty-three percent of 1001 people in the general public and 57.5\% of 909 "civilian elites" 165 answered "yes."

Note that all of these polls were taken prior to women's unprecedented contributions in ground combat in Operations ENDURING FREEDOM and IRAQI FREEDOM.

161. Georgia C. Sadler, Women in Combat, The Polling Data, 119 U.S. NAVAL INST. Proc. 52 (Feb. 1993).

162. Id. at 52 .

163. Id. at 53 .

164. SUSAN J. GOLdING, WOMEN: READY FOR THE CHALLENGES OF THE FUtURE U.S. ARMED FORCES 7 (U.S. Army War College 2002), available at http://stinet.dtic.mil/cgi-bin/GetTRDoc?AD= ADA401888\&Location $=\mathrm{U} 2 \&$ doc $=$ GetTRDoc.pdf.

165. "Civilian elites" were "selected primarily from directories such as Who's Who, and include clergy, politicians, journalists, scholars, writers, labor leaders, and foreign policy professionals." Miller \& Williams, supra note 134, at 367.

166. Id. at 368 . 


\section{Body bags}

Since 9/11, seventy-five women have died in Iraq and Afghanistan, ${ }^{167}$ an unprecedented number of female combatant casualties. The American public is showing distaste for the total number of deaths, including both men and women, but there has been relatively little outrage regarding the number of women casualties in particular. We are at war, and all of these losses are difficult to accept. But a woman's life is no more valuable than the life of a man. Congresswoman Heather Wilson, the only female veteran in the U.S. House of Representatives, stated that the war in Iraq has settled the issue of whether the public will value the lives of fallen women soldiers over men. "There have been casualties, men and women, and we grieve for them. But I think we have gotten beyond the point where losing a daughter is somehow worse than losing a son." ${ }^{168}$

\section{POWs}

Critics of women in combat state that Americans are not ready to deal with women POWs and all the risks that go along with being captured. However, during World War II, seventy-nine American military women were POWs in the Philippines, five women were POWs in Guam, and one was a POW in Europe. ${ }^{169}$ Two female soldiers were taken prisoner in Operation DESERT STORM, ${ }^{170}$ and two additional female soldiers were held in the early days of Operation IRAQI FREEDOM. Elaine Donnelly, a well-known activist against women in the military, has placed a great deal of emphasis on the risks of rape as a POW. ${ }^{171}$ Although the risk exists for women, it also exists for men, and both accept that risk as a part of their job. In either case, rape is a violation of the Geneva Convention. ${ }^{172}$

In the current war, male and female reporters, contractors, and civilians are also vulnerable to being kidnapped, tortured, raped, and executed. These are the horrors of war with an enemy whose strategy ignores these conventions. All men and women occupying military positions that render them more vulnerable to capture go through extensive training to prepare for this treacherous situation; each soldier must think through and accept the risks of experiencing

167. The World: Women in Combat, supra note 19.

168. David Moniz, Female Amputees Make Clear that All Troops are on Front Lines, USA TODAY, Apr. 28,2005 , at $10 \mathrm{~A}$.

169. E-mail from Cushman, supra note 58.

170. WIMSA, Highlights, supra note 46.

171. See, e.g., Elaine Donnelly, Private Lynch and Amazon Myths, NAT'L Rev. (online ed.), Nov. 14, 2003, http:/ / www.nationalreview.com/comment/donnelly200311140914.asp.

172. Geneva Convention Relative to the Treatment of Prisoners of War, Aug. 12, 1949, arts. 1314, 6 U.S.T. 3316, 75 U.N.T.S. 135.

Prisoners of war must at all times be treated humanely. Any unlawful act or omission by the Detaining Power causing death or seriously endangering the health of a prisoner of war in its custody is prohibited, and will be regarded as a serious breach of the present Convention ... prisoners of war must at all times be protected, particularly against acts of violence ... and against insults .... Prisoners of war are entitled in all circumstances to respect for their honour. Women shall be treated with all the regard due to their sex.... 
potential horrors as a POW. ${ }^{173}$ And although the public is rightly outraged when any of our service members are captured, the lack of outrage about female POWs in particular undercuts this reason for excluding women from combat.

After analyzing the common arguments against women in combat, my conclusions are: (1) some women have the physical strength and stamina to fight in ground combat, and each recruit should be assessed individually; (2) women's mere presence in a unit is not a detriment to cohesion; and (3) the U.S. public seems supportive of qualified women serving in any roles that such women are qualified to fill. However, there are some issues and policies related to women in the military that have and will continue to impede our combat effectiveness and must be addressed seriously in order to ensure success when fully integrating female warriors into the combat arms.

\section{GENDER ISSUES AND POLICIES THAT DEGRADE COMBAT EFFECTIVENESS}

Little public discussion has focused on the less glamorous gender-related policies that directly impact the essential element of success in the battlespace: combat effectiveness. These policies and the military ethos must be changed to fully integrate women into our warfighting force. In my view, many of the policies discussed below are "holdovers" from our past when women were restricted to more traditional cultural roles in society and the military. These policies seek paternalistically to preserve elements of femininity that reduce training effectiveness, set roadblocks to gender integration, and inculcate double standards. In the author's opinion, the current ethos is partly a result of an overreaction to correcting real discrimination towards women in the past. For some of these issues, the pendulum needed to swing, but it has swung too far in the other direction and the results are destructive. The negative effects of these policies are used as fodder by critics of women's integration into the military and are misconstrued as being caused by the mere presence of women. In reality, these policies promulgate actual or perceived double standards for and against women that ultimately degrade the warfighting team. As a female who has commanded a combat aviation squadron, I believe these policies and our ethos should be changed in order to increase the overall combat effectiveness of our armed forces.

\section{A. Pregnancy}

Once a reason for mandatory discharge, pregnancy is now considered a normal condition that is consistent with a military career. Current DoD policy allows a pregnant woman to request a release from her commitment to the

173. In the past, those personnel characterized as having a "high risk of capture"-i.e., fighter pilots, special operations personnel-were the only ones identified for the intensive training called survival, evasion, resistance, and escape (SERE). The author has attended this training. Several "prisoners" in recent conflicts were not identified as being in positions that had a "high risk of capture," and therefore had little to no SERE training-for example, Jessica Lynch's unit. The military is still grappling with where to draw the line for SERE training eligibility in a 360-degree war. It is unclear at this point whether the fifteen British military hostages held in Iran in April 2007 had any SERE-type training. 


\section{WOMEN IN COMBAT: IS THE CURRENT POLICY OBSOLETE? 1045}

military, subject to approval by the service. ${ }^{174}$ Moreover, current DoD policy does not discourage pregnancy while in assignments that would remove the women from their primary duties for over a year (such as fighter pilot assignments) or pregnancy during periods of deployment vulnerability. ${ }^{175}$ Consequently, a poorly-timed pregnancy in today's high tempo military ${ }^{176}$ consisting of over fourteen percent women-can have a significant effect on military effectiveness. ${ }^{177}$ Harrell and Miller discovered this during their study on women's effect on readiness.

We heard many times that who was pregnant and when she was pregnant made a tremendous difference to unit readiness. There was a general perception that women officers and senior enlisted personnel try to time their pregnancies to have the least effect upon the unit-e.g., not before a scheduled deployment. This was due, in part, to their pride in and concern regarding their units and also because, we were told, these women had invested a lot of time in their careers and would not want to damage them. These opinions stood in marked contrast to those concerning junior female personnel, especially single mothers. Single, pregnant, junior enlisted personnel were considered the most problematic because the pregnancies were less likely to be planned and more likely to create other problems, such as financial and child-care problems, that impacted the unit. ${ }^{178}$

The military is unlike any other organization: Its purpose is the defense of the nation. The military must foster a culture in which military women understand that it is not appropriate to get pregnant whenever they desire. Instead, women need to realize their duties take precedence. They must take measures to prevent unplanned pregnancies and plan for pregnancies to occur only when they are in non-deployable situations. Expansion of women's roles in uniform, the shrinking of the force, and the high operations tempo, where every military position is vulnerable to deploy, has made this even more crucial than in the past. Military leaders must create a climate where commanders are not afraid to talk about pregnancy as a readiness issue and to counsel female

174. The military services can deny the request due to needs of the military; however, the author is aware of requests approved by the Air Force.

175. The USAF assigns every position to an Air Expeditionary Force-a cycle of four months deployment vulnerability followed by fifteen months recovery, routine training, and preparation for the next deployment. Many high-demand specialties are on a higher tempo, but all the services are attempting to tell servicemen and women when they are scheduled to deploy next, barring unforeseen circumstances.

176. By high tempo, the author means high deployment rate, duration, and frequency. Every person in every unit matters to meet the mission demands, and having even a small percentage unable to deploy at any time can place significant strains upon the unit, including the personnel who must replace those unable to deploy.

177. DoD policy prohibits pregnant women from deploying overseas or participating in activities that would potentially be dangerous to the baby. Navy and Marine Corps policies state that pregnant women must be within six hours of a hospital. Harrell \& Miller, supra note 139, at 39. For a fighter pilot flying in an ejection seat aircraft, a pregnant pilot is grounded immediately and unable to do her primary job for almost a full year. After not flying for at least ten months, a pilot must go through a formal requalification training program in order to become combat ready. While grounded, the overall combat readiness of the squadron is diminished.

178. Id. at $40-41$. 
warriors on their obligation to avoid pregnancies when it will negatively impact unit readiness. ${ }^{179}$ The issue is intent, which is difficult to enforce except through strong leadership, a call to dedication and integrity, and proper counseling for military women.

While pregnancy is a temporary condition, parenthood is a permanent one that affects both servicemen and servicewomen. Single parents and dualmilitary parents are obligated to have a plan for care of their children in event of deployment and many manage their duties and parenthood admirably. Servicewomen should not be allowed to avoid their service obligations merely because they become pregnant. ${ }^{180}$

\section{B. Double Standards}

Another dynamic that may decrease cohesion in gender-integrated units is the appearance or reality of a double standard. If the military is truly to be a warfighting team with gender-neutral standards, it must abolish all policies that appear to make things easier or different for women, including those that demean them. Harrell and Miller found that some "[l]eaders create resentment between men and women by holding them to different standards or giving them assignments or recognition based on gender." ${ }^{181}$ Although gender was not cited as a major factor in determining the morale of gender-integrated units, "[t]o the extent that gender affected morale, the perception of different standards or policies for men and women was a frequently cited source of morale problems." ${ }^{182}$ It is my view that these perceptions are born during the first phase of transition into military life, basic training, and are reinforced by other policies throughout service members' careers.

\section{Basic Training}

When I entered the Air Force Academy, we went through genderintegrated basic training. It was challenging for all, but women simply needed to be in much better shape for their gender than men. As a senior, I was in charge of the hardest course in basic training, the Assault Course. We taught basic warfighting skills and it was physically exhausting for both men and women. It is my judgment that gender-segregated basic training is not conducive to building an effective warfighting team and only plants the seed that women are inferior partners in uniform. Watered down gender-integrated training that caters to weak women diminishes the training experience for all. The military needs gender-integrated basic training that demands women recruits perform to a very high standard of fitness in which both men and women are challenged.

179. The author realizes accidents may happen, and units should deal with them just like unplanned injuries and illnesses. There is a fine line between creating an ethos that addresses this issue seriously and not encouraging women to have abortions or endanger the health of their babies for fear of potential career implications.

180. It is the author's recommendation that young service women, especially, need to be counseled about the foolishness of entering into a lifetime commitment (motherhood) in order to be released early from a four or six year commitment to serve in the military.

181. HARRELL \& MiLLER, supra note 139, at 63 (alteration added).

182. Id. at 80 (alteration added). 


\section{WOMEN IN COMBAT: IS THE CURRENT POLICY OBSOLETE? 1047}

When men enter basic training, the military shaves their heads. This policy is intended to take away the person's individuality and build him into a warrior who is a part of a team greater than himself. The head-shaving procedure is a significant event on the first day of a young man's transition into the military. When women enter basic training (for the Air Force), their hair is not cut. Women are directed to style their hair in accordance with policies on personal appearance as they watch their male teammates get their heads shaved. This sets the tone for a double standard that impacts the way men and women treat each other for the rest of their time in service.

Assuming the head-shaving ritual is beneficial for the transformation from civilian to warrior, this policy does not allow women to experience that same significant, symbolic event on their journey to becoming warriors. This double standard is indefensible and needs to be changed. ${ }^{183}$ The issue was seriously (and emotionally) debated upon admitting the first women to the Virginia Military Institute. The final decision was that women got a "short-sheared cut" of approximately one-inch long for the first six weeks of basic training and then are able to grow it out to a short style for the remaining six months of the first year. After that, they, like the male cadets, can grow it out further as long as they remain within regulations. This would be a reasonable alternative to the current Air Force policy. ${ }^{184}$

\section{Uniforms}

When women served in WWII, they initially wore the same uniform as men, which caused functional and practical obstacles for some women. Over time, the women's uniform was modified substantially. In the 1950s and 1960s, a great deal of emphasis was placed on ensuring that women looked "feminine," even under grueling conditions in the combat zone. ${ }^{185}$ These attitudes impact the uniform women wear today.

Currently in the Air Force, other than the battle dress uniform and flight suit, women's uniforms have an entirely different look than men's. ${ }^{186}$ Women are allowed to wear skirts, pumps, and pantyhose when in their "blues." ${ }^{187}$ Women have a light blue shirt that is allowed to be untucked from their blue pants. ${ }^{188}$ Women must wear a long skirt and heels when in formal dress uniform. ${ }^{189}$ The differences have become ridiculous at times: Until one year ago, women's cummerbunds on their formal uniform were worn with the pleats down, while

183. LaURA FaIRChILD BRODIE, VMI, AND the COMING OF WOMEN 131 (N.Y., Pantheon Books 2000).

184. The author did not research the basic training policies of the other services. If they also allow women to keep their hair long, their policies should likewise be modified to eliminate the double standard and its effects.

185. HOLM, supra note 43 , at $181-82$.

186. See generally Dep't of the Air Force, Air Force Instruction (AFI) 36-2903, Dress and Personal Appearance of Air Force Personnel (Aug. 2, 2006), http://www.e-publishing.af.mil/pubfiles/af/36/ afi36-2903/afi36-2903.pdf [hereinafter AFI 36-2903].

187. Id. at $68-71$.

188. Id. at 64 .

189. Id. at $67-68$ 
men's are directed to be worn with pleats up. ${ }^{190}$ Women have a different flight cap than men. ${ }^{191}$ And women's belts face the opposite direction of men's belts. ${ }^{192}$

Most police and fire departments have gender-neutral uniform styles. ${ }^{193}$ The need for different sizes and cuts in order to better fit a woman's body and look professional is understandable, but any other differences in uniforms only accentuates our differences. It is called a "uniform" for a reason: it makes everyone look the same. While women do not have to be masculine to serve in the military, when your line of work is the defense of the nation, there is no place for high heels, pantyhose, and skirts above the knee.

\section{Double standards that demean or patronize female warriors}

If we are to treat all military members equally, the DoD must ensure that it also eliminates double standards that are demeaning or patronizing to women. This includes different standards based on the excuse of adhering to "cultural norms" or "host nation sensitivities." I spent over seven years of my career trying to eliminate the policy that required non-Muslim U.S. servicewomen to wear the traditional Muslim abaya (burqa) in Saudi Arabia. This policy, along with others that treated military women as second-class citizens, degraded the good order and discipline of the military by creating a double standard that was demeaning to women. It affected the way military men treated and viewed military women. In the end, after the Department of Defense refused to rescind the policy, Congress unanimously passed an amendment to the 2003 Defense Authorization Act that overturned the policy. ${ }^{194}$ Other policies that demean or patronize female warriors should be identified and eliminated.

\section{Selective Service registration}

Since the birth of our republic, citizenship has entailed certain rights and obligations. At times these obligations include military service. ${ }^{195}$ It is the public

190. Uniform Board Results Released, AIR FORCE LINK (online), Feb. 8, 2006, http://www.af.mil/ news/story.asp?id=123016142.

191. AFI 36-2903, supra note 186, at 32. As of 2006, women are now authorized to wear the more traditional "male" flight cap on an optional basis, due in part to efforts by the author. See Uniform Board Results Released, supra note 190.

192. AFI 36-2903, supra note 186, at 51, 68.

193. See, e.g., Iowa City Police, Personal Appearance and Uniform Regulations (May 23, 1994), http://www.icgov.org/policefiles/genorder4.pdf; Red Oaks, Tex., Fire Department, Dress and Appearance Code, http://www.redoaktx.org/departments/fire-rescue/sop-sogs/general-guide lines/2006/10/39 (last visited Apr. 2, 2007).

194. See Bob Stump National Defense Authorization Act for Fiscal Year 2003, Pub. L. No. 107-314, $\S 563,116$ Stat. 2458 (2002). See also Amended Complaint for Deprivation of Constitutional and Statutory Rights at IIII 13-20, McSally v. Rumsfeld, No. CV-02481 (D.D.C. May 3, 2002), available at http://www.neubergerlaw.com/McSally\%20Amended\%20Complaint.PDF, dismissed with prejudice per stipulation of the parties, No. CV-02481 (D.D.C. Apr. 24, 2004) (unpublished disposition), cited in Petition for Writ of Certiorari at 16, McSally v. Rumsfeld, No. 05-40 (U.S. July 1, 2005) (presenting the procedural question of an award of attorneys' fees; conceding that the underlying substantive question was mooted by the National Defense Authorization Act for Fiscal Year 2003, Pub. L. No. 107-314, §563), available at 2005 WL 1596607.

195. The connection between citizenship and service was a primary argument for the abolition of slavery after the Civil War, where advocates claimed that Black Americans had "bought their rights 


\section{WOMEN IN COMBAT: IS THE CURRENT POLICY OBSOLETE? 1049}

policy of our republic that the obligation of military be shared generally. Section 451 of the Military Selective Service Act (MSSA) of 1948 provides:

The Congress declares that an adequate armed strength must be achieved and maintained to insure [sic] the security of this nation. Congress further declares that in a free society the obligations and privileges of serving in the armed forces and the reserve components thereof should be shared generally, in accordance with a system of selection which is fair and just, and which is consistent with the maintenance of an effective national economy. ${ }^{196}$

Section 453 of the MSSA empowers the President, by proclamation, to require the registration of "every male citizen" and resident alien between the ages of eighteen and twenty-six. ${ }^{197}$

In Rostker v. Goldberg, the Supreme Court considered whether male-only registration under the MSSA violated the equal protection component of the Due Process Clause of the Fifth Amendment. ${ }^{198}$ The Court upheld the male-only registration policy, expressing the need for "healthy deference to legislative and executive judgments in the area of military affairs." ${ }^{199}$ The Court side-stepped a full equal protection analysis of the male-only draft restriction, reasoning that because women were not eligible to serve in combat, men and women were not similarly situated for the purposes of the registration exemption:

The existence of combat restrictions clearly indicates the basis for Congress' decision to exempt women from registration. The purpose of registration was to prepare for a draft of combat troops. Since women are excluded from combat, Congress concluded that they would not be needed in the event of a draft, and therefore decided not to register them. ${ }^{200}$

The Rostker decision begs the question: If direct ground combat is opened to women, and if the Fifth Amendment requires that both men and women comply with selective service obligations, should women be compelled to serve in direct ground combat if drafted? In my view, men and women should serve in the positions for which they are best qualified, in light of their physical capabilities and other objective measures. Citizens' rights and responsibilities should be gender-neutral. ${ }^{201}$ Some argue that droves of women will get pregnant to avoid the possibility of serving in combat. However, the reality is that men

with blood." LORY M. FENNER \& MARIE E. De YOUnG, WOMEN IN COMBAT: CiVIC DUTY OR MiLITARY LIABILITY? 54 (Georgetown Univ. Press 2001).

196. Military Selective Service Act of 1948, §451, 62 Stat. 604 (80th Cong., 2d Sess. 1948) (emphasis added).

197. Id. at $\S 453$.

198. 453 U.S. 57 (1981).

199. Id. at 66

200. Id. at 70, 77 (emphasis added).

201. For a detailed analysis of the issue of the draft as an obligation of citizenship for men and women, see FENNER \& DE YOUNG, supra note 195. I realize that I am in the minority in stating that qualified women might be forced into ground combat in the future as an implication of the policy change. When 906 civilian elite and 710 military elite were asked if women should be required to serve in all combat jobs, only $13.9 \%$ of the civilians and $12.7 \%$ of the military answered "yes." Miller \& Williams, supra note 134, at 369. 
who are unwilling to fight may also find ways to avoid their service obligations, and we should deal with both of these issues during the execution phase.

Adjustments to the military ethos regarding pregnancy and double standards will enhance current and future integration of women warriors into the military warfighting team. This climate change, along with the policy and legislative recommendations articulated below, will fully integrate women in a manner that maximizes combat effectiveness.

\section{POLICY AND LEGISLATIVE RECOMMENDATIONS}

Just as Operation DESERT STORM provided the justification to eliminate many restrictions on women's roles in the military, Operations IRAQI FREEDOM and ENDURING FREEDOM illustrate the obsolescence of the ground combat exclusion and should serve as the justification to further expand women's roles in the military. As women's roles expand, the military must ensure maximum effectiveness of its fighting force. This can be done by evaluating recruits as individuals, creating a leadership climate that maximizes unit cohesion, and adjusting our ethos to eliminate double-standards and other hold-over gender policies and attitudes from the past. I recommend the following policy and law changes:

\section{A. Rescind the Collocation Policy}

The collocation policy was intended to minimize the risk of combat to women in combat support positions, but the realities of modern warfare have made this restriction obsolete. All combat support personnel are vulnerable to the risks of combat and are now being trained to ensure readiness for combat operations. In practice, the collocation policy merely restricts assignment flexibility during a time of strained personnel tempo. The DoD should immediately notify Congress that it is rescinding the collocation rule, in order to align current policy with the realities of combat today and to provide assignment flexibility to combat commanders. This would open over eighty thousand combat support positions to women. ${ }^{202}$

\section{B. Adopt Gender-Neutral Criteria for Assignments}

The military services should adopt a gender-neutral meritocratic approach for assigning enlistees to specific positions. Potential servicemen and women should be considered as individuals, not as members of a particular race, religion, or gender. A gender-neutral, capabilities-based assignment system would provide maximum flexibility for military leadership during the planning and execution of combat operations.

This approach is similar to that articulated by the Honorable Edwin Dorn, Undersecretary of Defense for Personnel and Readiness, when he testified before the House Armed Services Committee Subcommittee on Military Forces and Personnel in 1994. Undersecretary Dorn stated: 


\section{WOMEN IN COMBAT: IS THE CURRENT POLICY OBSOLETE? 1051}

Readiness is enhanced when we remove unnecessary impediments to the recruitment, training, and use of people. During the past year-and-a-half, the Department has made major progress in removing such impediments. As a result, some 260,000 more jobs in the military can be filled by either men or women. This represents an increase in the flexibility that the Services need to maintain readiness. Altogether, about $80 \%$ of all jobs in the armed services and more than $90 \%$ of military career fields can now be filled by the best qualified and available person, man or woman. ${ }^{203}$

This logic should extend to the remaining career fields and positions. If the goal is to field the most capable fighting force, a policy that excludes fifty-one percent of the population from twenty percent of military positions is neither efficient nor wise. America must pick the best "man" for every military job-even if she is a woman.

\section{Rescind the Ground Combat Exclusion Policy}

The DoD should notify Congress that it intends to rescind the ground combat exclusion policy, opening all ground jobs to any person who is qualified to fill those positions, regardless of gender. This would open approximately 180,000 positions to qualified women who desire to serve in combat roles. ${ }^{204} \mathrm{By}$ law, DoD must notify Congress in advance of rescinding this policy. It will also take some time for the services to ensure that training facilities and leadership are ready to receive women into the training pipeline for combat positions. Additionally, leadership must take steps to inform and educate male-only combat units that qualified women warriors will soon be entering their units, standards will not be lowered, and denigration will not be tolerated. Recruiters and MEPS staff must also receive guidance on how to counsel all recruits on this change and utilize the capabilities and desires of all male and female recruits to maximize readiness.

D. Rescind the Policy that Permits Servicewomen to Avoid their Commitments Due to Pregnancy

The Department of Defense should rescind the policy that allows servicewomen skirt their commitment to the military due to pregnancy. It must also create a climate where commanders are encouraged to counsel military women on their responsibilities to not plan a pregnancy during deployment vulnerability times or when serving in jobs where pregnancy would prohibit them from conducting their primary duties.

\section{E. Eliminate Double Standards.}

All the military services should review their policies, starting with basic training, to eliminate double standards that favor women, demean women, or treat them differently than their male counterparts. For example: all basic training should be gender-integrated and challenging for both men and women.

203. Assignment of Army and Marine Corps Women Under the New Definition of Ground Combat: Hearing Before the Subcomm. on the Mil. Forces \& Personnel of the H. Comm. on the House Armed Services, 103d Cong (1994) (statement of the Honorable Edwin Dorn, Under Secretary of Defense).

204. Id. 
Women's hair should be at least cut extremely short upon entering basic training in all services. Uniforms should be standardized, and skirts, high heels, and pantyhose should be removed from the military uniform.

\section{F. Amend the Military Selective Service Act to Include Women}

Congress should amend the Military Selective Service Act to include women. Indeed, the Equal Protection Clause may compel this change if the ground combat exclusion policy is lifted. ${ }^{205}$ Amending the Selective Service Act will provide the widest pool of candidates from which to choose for all military roles in the case of a national emergency and will ensure that American women participate in the most basic obligation of citizenship.

\section{CONCLUSION}

The United States is engaged in a long-term Global War on Terrorism. To fight this war, America must field the most capable and flexible military force possible. Some think that military readiness and increased roles for women in the military are mutually exclusive objectives. On the contrary, the evidence indicates these objectives are mutually reinforcing. If the goal is to field the most capable force, a policy that excludes the majority of the population from even being considered to serve in over 200,000 military positions is inefficient and only decreases military flexibility. Like previous prohibitions against women flying combat aircraft or serving on combat vessels, the ground combat exclusion policy was shaped by antiquated views regarding the "proper" role of women.

The ground combat exclusion itself suffers from obsolescence. Modern warfare is no longer linear; combat occurs in a 360-degree battlefield around all combat and combat support forces. Women soldiers are at risk of being injured, captured, or killed and are displaying incredible skill and courage in combat situations. The Army is transforming into a modular fighting system where restrictions on assignment of women limit flexibility. The Army is also increasing its end strength and continues to lower standards to fill its recruitment quotas. Given these realities, the military needs to recruit from one hundred percent of the population for positions that each is best qualified to fill.

Common arguments against women serving in ground combat are not sufficient to exclude all women from being considered for combat roles. Some women have the physical strength to fill ground combat assignments, just as some men do not. Assessing recruits as individuals can provide the most capable and flexible fighting force. Women do not, by their mere presence, diminish cohesion in a warfighting unit. And the American public is willing to have women serve in any role in the All-Volunteer Force for which they are qualified.

205. In Rostker v. Goldberg, the Supreme Court side-stepped full Equal Protection analysis of the Military Selective Service Act's registration provisions because, in light of the exclusion of women from combat, men and women were not similarly situated with respect to registration for the draft. 453 U.S. 57, 77 (1981). See also supra note 200 and accompanying text. 
Throughout 230 years of history and many conflicts, American women have shown great courage in service to their country despite restrictions in their military roles. Incrementally, laws and policies have changed to open more and more positions to women as they prove their worth and as cultural views evolve. The military is now at another historic crossroads: The time has come to rescind the obsolete and counterproductive ground combat exclusion policy.

At the same time, a comprehensive reengineering of gender-related policy is essential to attain maximum combat effectiveness. Effectiveness is degraded when women and men are accessed, evaluated, inculcated, conditioned, trained, and assigned differently because of gender. In order to integrate men and women as equal warriors on the most effective combat team, the DoD needs to end some holdover policies that were founded in years when military women held more traditionally "female" positions. Double standards that favor or demean women must be identified and eliminated. A modified ethos is necessary where men and women serve under equal expectations, respect, and accountability-where both women and men place service and ultimate victory first and demure the notion of disparate prerogatives based on gender norms.

"No women in combat" may be the policy recently affirmed by the Commander-in-Chief, but it is not the reality of the current war. The 1994 combat exclusion policy feebly attempts to build a concrete wall between combat and non-combat with intent to exclude American women from ground combat. Yet, like previous policies and laws that tried to wall off women from air and sea combat, the distinction is imaginary and this policy is obsolete. Despite this formal exclusion, women have marched into direct fire. Fortunately, American women have proven they are capable of fighting in ground combat. To fight the long war ahead, America needs a policy that assigns both men and women to positions for which they are qualified-with no limiting exclusions-based on physical and intellectual capabilities, leadership skills, and aptitude. With a new Congress and Secretary of Defense, the time is ripe to abrogate this obsolete policy once and for all. By law, the Secretary needs only to notify Congress of his intent to remove this last barrier for fully utilizing our women in uniform. "Mr. Secretary, tear down this wall." 


\section{APPENDIX A}

\section{POSITIONS CLOSED TO WOMEN AS OF $2005^{206}$}

\begin{tabular}{|c|c|}
\hline \multicolumn{2}{|c|}{ U.S. ARMY } \\
\hline POSITION, WEAPON SYSTEM, AND FIELD OF SKILLS & RATIONALE FOR THE APPLICABILITY \\
\hline Infantry & Direct ground combat primary mission \\
\hline 11A Infantry Officer & Direct ground combat primary mission \\
\hline 11B Infantryman & Direct ground combat primary mission \\
\hline 11C Indirect Fire Infantryman & Direct ground combat primary mission \\
\hline $11 Z$ Infantry Senior Sergeant & Direct ground combat primary mission \\
\hline Armor & Direct ground combat primary mission \\
\hline 12A/B Armor Officer & Direct ground combat primary mission \\
\hline 12C Cavalry Officer & Direct ground combat primary mission \\
\hline 19D Cavalry Scout & Direct ground combat primary mission \\
\hline 19K M1 Abrams Armor Crewman & Direct ground combat primary mission \\
\hline 19Z Armor Senior Sergeant & Direct ground combat primary mission \\
\hline Special Forces & Direct ground combat primary mission \\
\hline 18A Special Forces Officer & Direct ground combat primary mission \\
\hline 180A Special Forces Warrant Officer & Direct ground combat primary mission \\
\hline 18B Special Forces Weapons Sergeant & Direct ground combat primary mission \\
\hline 18C Special Forces Engineer Sergeant & Direct ground combat primary mission \\
\hline 18D Special Forces Medical Sergeant & Direct ground combat primary mission \\
\hline 18E Special Forces Communications Sergeant & Direct ground combat primary mission \\
\hline 18F Special Forces Asst Operations \& Intel Sergeant & Direct ground combat primary mission \\
\hline 18Z Special Forces Senior Sergeant & Direct ground combat primary mission \\
\hline Ranger & Direct ground combat primary mission \\
\hline Field Artillery & Collocation with direct ground combat units \\
\hline 13B Cannon Crewmember & Collocation with direct ground combat units \\
\hline 13C Tactical Automated Fire Control Systems Specialist & Collocation with direct ground combat units \\
\hline $\begin{array}{l}\text { 13D Field Artillery Automated Tactical Data Sys } \\
\text { Specialist }\end{array}$ & Collocation with direct ground combat units \\
\hline 13E Cannon Fire Direction Specialist & Collocation with direct ground combat units \\
\hline 13F Fire Support Specialist & Collocation with direct ground combat units \\
\hline $\begin{array}{l}\text { 13M Multiple Launch Rocket System (MLRS) } \\
\text { Crewmember }\end{array}$ & Collocation with direct ground combat units \\
\hline 13P MLRS Operational Fire Direction Specialist & Collocation with direct ground combat units \\
\hline 13R Field Artillery Firefinder Radar Operator & Collocation with direct ground combat units \\
\hline Air Defense Artillery & Collocation with direct ground combat units \\
\hline 14B Short Range Air Defense Artillery Officer & Collocation with direct ground combat units \\
\hline 140B FAAD Systems Technician & Collocation with direct ground combat units \\
\hline 14R Bradley Linebacker Crewmember & Collocation with direct ground combat units \\
\hline 14S Avenger Crewmember & Collocation with direct ground combat units \\
\hline Combat Engineer Line Companies & Collocation with direct ground combat units \\
\hline 12B Combat Engineer & Collocation with direct ground combat units \\
\hline Ground Surveillance Radar Platoons & Collocation with direct ground combat units \\
\hline 96R Ground Surveillance Systems Operator & Collocation with direct ground combat units \\
\hline Mechanical Maintenance & Collocation with direct ground combat units \\
\hline 45D Self Propelled Field Artillery Turret Mechanic & Collocation with direct ground combat units \\
\hline 45E M1 Abrams Tank Turret Mechanic & Collocation with direct ground combat units \\
\hline 45N / 63N M60A1/A3 Tank Turret/ System Mechanic & Collocation with direct ground combat units \\
\hline 45T Bradley Fighting Vehicle System Turret Mechanic & Collocation with direct ground combat units \\
\hline 63A M1 Abrams Tank System Maintainer & Collocation with direct ground combat units \\
\hline 63D Artillery Mechanic & Collocation with direct ground combat units \\
\hline 63E M1 Abrams Tank System Mechanic & Collocation with direct ground combat units \\
\hline
\end{tabular}

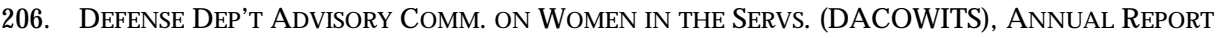
on Status of Female Members of the ARMEd Forces OF the United States, FY2002-05, at 2-6, available at http://www.dtic.mil/dacowits/docs/feb2006/StatusofWomenFinal_05.doc. 


\section{WOMEN IN COMBAT: IS THE CURRENT POLICY OBSOLETE? 1055}

\begin{tabular}{|l|l|}
\hline \multicolumn{2}{|c|}{ U.S. ARMY } \\
\hline POSITION, WEAPON SYSTEM, AND FIELD OF SKILLS & RATIONALE FOR THE APPLICABILITY \\
\hline $\begin{array}{l}\text { 63M / 63T Bradley Fighting Vehicle system Maintainer } \\
\text { / Mech }\end{array}$ & Collocation with direct ground combat units \\
\hline 63N M60A1/A3 Tank System Mechanic & Collocation with direct ground combat units \\
\hline 63T Bradley Fighting Vehicle System Mechanic & Collocation with direct ground combat units \\
\hline
\end{tabular}

\begin{tabular}{|l|l|}
\hline \multicolumn{2}{|c|}{ U.S. AIR FORCE } \\
\hline POSITION, WEAPON SYSTEM, AND FIELD OF SKILLS & RATIONALE FOR THE APPLICABILITY \\
\hline $\begin{array}{l}\text { 11SXA and 11SXB-Special Ops Rotary Wing Pilot- } \\
\text { restricted weapon systems MH-53 and MH-60 only }\end{array}$ & Collocation with direct ground combat units \\
\hline $\begin{array}{l}\text { 13DX—Control and Recovery (Includes suffixes A- } \\
\text { Combat Rescue, and B-Special Tactics) }\end{array}$ & Collocation with direct ground combat units \\
\hline $\begin{array}{l}\text { 15WX (restricted positions when serving with the } \\
\text { Army)-Weather }\end{array}$ & Collocation with direct ground combat units \\
\hline $\begin{array}{l}\text { 11XXU and 12XXU—Pilot and Navigator Air Liaison } \\
\text { Officer }\end{array}$ & Collocation with direct ground combat units \\
\hline 1T2X1-Pararescue & Collocation with direct ground combat units \\
\hline 1C2X1-Combat Control & Collocation with direct ground combat units \\
\hline 1C4X1-Tactical Air Command And Control & Collocation with direct ground combat units \\
\hline 1A1XB-Flt Engineer/Gunner MH-53, MH-60 & Collocation with direct ground combat units \\
\hline 1W0X1-Weather & Collocation with direct ground combat units \\
\hline 2E1X3-Ground Radio Comm & Collocation with direct ground combat units \\
\hline 3C1X1-Radio Communications Systems & Collocation with direct ground combat units \\
\hline Tactical Air Command And Control Helper & Collocation with direct ground combat units \\
\hline Pararescue Helper & Collocation with direct ground combat units \\
\hline
\end{tabular}

\begin{tabular}{|l|l|}
\hline \multicolumn{2}{|c|}{ U.S. MARINE CORPS } \\
\hline POSITION, WEAPON SYSTEM, AND FIELD OF SKILLS & RATIONALE FOR THE APPLICABILITY \\
\hline 0302 a Infantry Officer & Direct ground combat primary mission \\
\hline 0303 a light-Armored Vehicle Officer & Direct ground combat primary mission \\
\hline 0306 a Infantry Weapons Officer & Direct ground combat primary mission \\
\hline 0802 a Field Artillery Officer & Direct ground combat primary mission \\
\hline 1802 a Tank Officer & Direct ground combat primary mission \\
\hline 1803 a Assault Amphibian Vehicle Officer & Direct ground combat primary mission \\
\hline 0840 a Naval Surface Fire Support Planner & Direct ground combat primary mission \\
\hline 0845 a Naval Gunfire Spotter & Direct ground combat primary mission \\
\hline 0803 a Target Acquisition Officer & Direct ground combat primary mission \\
\hline 0311 a Rifleman & Direct ground combat primary mission \\
\hline 0313 a LAV Crewman & Direct ground combat primary mission \\
\hline 0321 a Reconnaissance Man & Direct ground combat primary mission \\
\hline 0331 a Machinegunner & Direct ground combat primary mission \\
\hline 0341 a Mortar Man & Direct ground combat primary mission \\
\hline 0351 a Assaultman & Direct ground combat primary mission \\
\hline 0352 a Anti-Tank/Assault Guided Missileman & Direct ground combat primary mission \\
\hline 0369 a Infantry Unit Leader & Direct ground combat primary mission \\
\hline 1812 a M1A1 Tank Crewman & Direct ground combat primary mission \\
\hline 1833 a Assault Amphibious Vehicle Crewman & Direct ground combat primary mission \\
\hline 0811 a Field Artillery Cannoneer & Direct ground combat primary mission \\
\hline 0844 a Field Artillery Fire Control Man & Direct ground combat primary mission \\
\hline 0861 a Fire Support Man & Direct ground combat primary mission \\
\hline 0842 a Field Artillery Radar Operator & Direct ground combat primary mission \\
\hline 0848 a Field Artillery Operations Man & Direct ground combat primary mission \\
\hline 0847 a Artillery Meteorological Man & Direct ground combat primary mission \\
\hline
\end{tabular}


1056 DUKE JOURNAL OF GENDER LAW \& POLICY

Volume 14:1011 2007

\begin{tabular}{|c|c|}
\hline \multicolumn{2}{|c|}{ U.S. NAVY ${ }^{207}$} \\
\hline POSITION, WEAPON SYSTEM, AND FIELD OF SKILLS & RATIONALE FOR THE APPLICABILITY \\
\hline Special Warfare SEAL Officer and SEAL Enlisted & Direct ground combat primary mission \\
\hline $\begin{array}{l}\text { Enlisted Explosive Ordnance Disposal Technicians and } \\
\text { Special Operations Officers who are integrated with } \\
\text { Special Warfare/Special Forces Units }\end{array}$ & Direct ground combat primary mission \\
\hline $\begin{array}{l}\text { Special Warfare Combatant Craft Crewmember } \\
\text { (includes Surface Warfare Officers assigned to Special } \\
\text { Boat Units) }\end{array}$ & Direct ground combat primary mission \\
\hline $\begin{array}{l}\text { Special Operations Independent Duty } \\
\text { Corpsman/Special Operations Technician Corpsman } \\
\text { (SEAL Hospital Corpsman Navy Enlisted Code } \\
8491 / 8492 \text { ) }\end{array}$ & Direct ground combat primary mission \\
\hline $\begin{array}{l}\text { Support personnel assigned to Naval Special Warfare } \\
\text { Development Group (Information Systems Technician, } \\
\text { Electronics Technician, Construction Mechanic - } \\
\text { positions are doctrinally required to physically } \\
\text { collocate and remain with direct ground combat units } \\
\text { closed to women) }\end{array}$ & Collocation with direct ground combat units \\
\hline $\begin{array}{l}\text { Support personnel assigned to Joint Communications } \\
\text { Unit (Information Systems Technician, Electronics } \\
\text { Technician - positions are doctrinally required to } \\
\text { physically collocate and remain with direct ground } \\
\text { combat units closed to women) }\end{array}$ & Collocation with direct ground combat units \\
\hline $\begin{array}{l}\text { Air Naval Gunfire Liaison Companies (ANGLICO) } \\
\text { (Surface Warfare Officer) }\end{array}$ & Collocation with direct ground combat units \\
\hline $\begin{array}{l}\text { Infantry Regiment and below (Medical Corps Officer; } \\
\text { Chaplain Corps Officer; Religious Program Specialist }\end{array}$ & Collocation with direct ground combat units \\
\hline $\begin{array}{l}\text { Tank Battalion and below (Medical Corps Officer; } \\
\text { Chaplain Corps Officer; Religious Program Specialist) }\end{array}$ & Collocation with direct ground combat units \\
\hline $\begin{array}{l}\text { Assault Amphibian Battalion and below (Medical } \\
\text { Corps Officer; Chaplain Corps Officer; Religious } \\
\text { Program Specialist; Navy Enlisted Explosive Ordnance } \\
\text { Disposal Technicians and Special Operations Officers } \\
\text { when assigned) }\end{array}$ & Collocation with direct ground combat units \\
\hline $\begin{array}{l}\text { Light Armored Reconnaissance Battalion (Medical } \\
\text { Corps Officer; Chaplain Corps Officer; Religious } \\
\text { Program Specialist) }\end{array}$ & Collocation with direct ground combat units \\
\hline $\begin{array}{l}\text { Combat Assault Battalion, } 3^{\text {rd }} \text { Marine Division (MAR } \\
\text { DIV) (Medical Corps Officer; Chaplain Corps Officer; } \\
\text { Religious Program Specialist) }\end{array}$ & Collocation with direct ground combat units \\
\hline $\begin{array}{l}\text { Force Reconnaissance Battalion, Marine Division } \\
\text { (Medical Corps Officer; Chaplain Corps Officer; } \\
\text { Religious Program Specialist) }\end{array}$ & Collocation with direct ground combat units \\
\hline $\begin{array}{l}\text { Artillery Battalion and below (Medical Corps Officer; } \\
\text { Chaplain Corps Officer; Religious Program Specialist) }\end{array}$ & Collocation with direct ground combat units \\
\hline $\begin{array}{l}\text { Combat Engineer Battalion and below (Medical Corps } \\
\text { Officer, Chaplain Corps Officer; Religious Program } \\
\text { Specialist) }\end{array}$ & Collocation with direct ground combat units \\
\hline $\begin{array}{l}\text { Special Amphibious Reconnaissance Independent Duty } \\
\text { Corpsman (Hospital Corpsman }\end{array}$ & Collocation with direct ground combat units \\
\hline $\begin{array}{l}\text { Marine Force Reconnaissance Corpsman (Hospital } \\
\text { Corpsman) }\end{array}$ & Collocation with direct ground combat units \\
\hline Medical Field Service Technician (Hospital Corpsman) & Collocation with direct ground combat units \\
\hline Submarines (SSN, SSBN, SSGN, AGSS, NR-1) & $\begin{array}{l}\text { Costs of appropriate berthing and privacy } \\
\text { arrangements are prohibitive }\end{array}$ \\
\hline $\begin{array}{l}\text { Patrol Coastal (PC) ships (due to inadequate berthing } \\
\text { and privacy requirements as well as doctrinal } \\
\text { requirement to physically collocate and remain with } \\
\text { direct ground combat units closed to women) }\end{array}$ & $\begin{array}{l}\text { Costs of appropriate berthing and privacy } \\
\text { arrangements are prohibitive }\end{array}$ \\
\hline
\end{tabular}

207. It is important to note that, regarding positions in the listed units, the Navy skill field itself is not closed to women-only the performance of that skill field on the specific, closed platform. 
WOMEN IN COMBAT: IS THE CURRENT POLICY OBSOLETE? 1057

\section{APPENDIX B}

\section{NON-U.S. EXAMPLES OF WOMEN IN COMBAT ${ }^{208}$}

WWI. The participation of Russian women in all roles including combat in WWI was unprecedented. At first, women served in a variety of support roles, some women combatants disguised themselves as men, and others were accepted to serve as combatants without being forced to disguise their gender.

Command personnel frequently used high praise in describing their female soldiers. While men hesitated, women often volunteered for dangerous reconnaissance missions and in many instances were the first to rush from trenches during attacks. Russia's women soldiers often proved more enthusiastic, better disciplined, more courageous and more self-sacrificing than their male compatriots. Many were even awarded high military honours like the St. George's Cross for their courage. ${ }^{209}$

By 1917, women were trained in separate all female units, both as an effort to use all resources against the Germans and Bolsheviks, and as an attempt to rally and shame the male troops into fighting. "That women could perform adequately in combat was demonstrated by the action of the 1st Russian Women's Battalion of Death on 9 July 1917. The battalion impressed senior male commanders and embarrassed German troops forced to surrender to them."210 Russian women's participation in WWI was a result of necessity as well as a political and cultural philosophy of social democracy that was emerging in Russia at the time, where equality and rights were granted to all. These rights also came with the obligation to defend the nation.

China. In 1934, the Chinese Communist Army began the famous "Long March," a 10,000-kilometer retreat following a blockade and attacks by Chiang Kai-Shek's Nationalist Army. "More than 2,000 of the women who joined the Red Army in the 1920s and early 1930s participated in the Long March." ${ }^{211}$ Little has been written about women's participation in this treacherous journey, which defined the first generation of Chinese Communists. Chinese culture consists of a mix of philosophies on women. Traditional Confucian beliefs held women in an inferior position to men in society. Mao Zedong, however, adopted a philosophy of the People's War, where an oppressor can only be overthrown if the entire population (men and women) was mobilized behind the war effort.

208. This section is not intended to be a comprehensive review of women's roles in the military throughout history, but instead some examples of their participation in a variety of societies and conflicts in the modern era. This section is meant only to provide data points to show that, due to or in spite of cultural norms, women have demonstrated that they are capable of fighting fiercely in combat.

209. Laurie Stoff, They Fought For Russia: Female Soldiers of the First World War, in A SOLDIER AND A Woman: SeXual Integration In the Military 66, 68-69 (Gerald J. DeGroot \& Corinna PenistonBird eds., Pearson Educ. Ltd. 2000).

210. Gerard J. DeGroot, Introduction: Arms and the Woman, in A SOLDIER AND A WOMAN, supra note 209 , at 3,11 .

211. Helen Praeger Young, Women at Work: Chinese Soldiers on the Long March, 1934-1936, in A SOLDIER AND A WOMAN, supra note 209, at 83. 
He successfully mobilized women in both the anti-Japanese war and the Chinese civil war.

WWII. In the modern era, WWII marked the most extensive participation of women throughout the ranks of several countries including the U.S., but the roles again demonstrated the tension between necessity and cultural norms. For example, Britain utilized mixed-gender anti-aircraft batteries, where women were trained in all positions but pulling the trigger. When Britain created the Home Guard, "[m]en deemed unfit for regular military service (or those in reserved occupations) were being organized into local defence units because the threat of German invasion seemed real."1212 Therefore, elderly and sick men joined, but women were prohibited from exercising the most fundamental obligation of citizenship. This demonstrates a circumstance where cultural norms weighed stronger than maximizing all resources for national defense.

Russia is an example where national survival and defense took precedence. After the German invasion of Russia in 1942, women fought in startling numbers in Russia in all capacities in the air and on the ground. For example, Russia trained three regiments of pilots: The 586th regiment of fighter pilots, the 587th bomber pilots, and the famous 588th night bombers, "who proved so effective at hitting their targets that they were nicknamed by the Germans the night witches." ${ }^{213}$ According to Soviet records, these women flew "a combined total of more than 30,000 combat sorties, produced at least 29 Heroes of the Soviet Union (of the 33 female aviators and 93 total women who received that medal) and included in their ranks at least three fighter aces." ${ }^{214}$ Russian women also fought extensively in ground combat.

Germany showed the most conservative philosophy towards the role of women in the military and combat. Hitler believed "Nazi women were to guarantee the survival of the Aryan race in the labor room, not on the battlefield. ${ }^{\prime 215}$ Nonetheless, women increasingly served in combat support in greater numbers (over 450,000) as the war progressed. Like Britain, Germany trained and utilized women in antiaircraft and searchlight positions with the same success, but they were also prohibited from actually firing the AA guns. In February 1945, Hitler directed the creation of an experimental woman's infantry battalion, but the war ended before they could be trained and employed. ${ }^{216}$

Vietnam. Mao Zedong's People's War philosophy was passed on to the Vietminh when China was providing advice to them in their struggle against their French rulers in the 1950s. Chinese Gen. Chen Geng was the senior military advisor to the Vietminh. Upon appointment to this role, he analyzed the readiness and ability of the Vietminh to defeat the French. In his diary, he wrote that "he discovered that the Vietminh neglected the mobilization of women in its struggle against the French. Since women constituted more than half of the

212. DeGroot, Introduction, in A SOLDIER AND A WOMAN, supra note 209, at 5 (alteration added).

213. Campbell, supra note 54, at 319.

214. Reina Pennington, "Do Not Speak of the Services You Rendered": Women Veterans of Aviation in the Soviet Union, in A SOLDIER AND A WOMAN, supra note 209, at 152, 153.

215. Campbell, supra note 54, at 313-14.

216. Id. at 317-18. 
Vietnamese population, Chen believed that ignoring them meant wasting more than half of the human resources. He pointed this out to Vietminh leaders." ${ }^{217}$

Although many women joined the resistance in the French-Indochina War, they were fully mobilized by Ho Chi Minh in the American war in Vietnam. Women served in a variety of roles during the war motivated by a great sense of patriotism and a call to defend their homeland. Many remained as guardians of their villages through service in the militia and anti-aircraft defense while continuing to work in the production of agriculture and industry. "Over 60,000 educated women worked as engineers, reporters, doctors and communications operators on the Ho Chi Minh Trail and the southern battlefields. The largest number entered the army through the volunteer youth corps." ${ }^{218}$ They endured brutal field conditions and demonstrated the ability to fight and lead in battle.

Israel. Since the creation of the Israeli Defense Force in 1948, both women and men have been conscripted, but women are now obligated to serve for two years versus three for the men. Contrary to popular myths, women have served primarily in support roles in the Israeli military in past conflicts with neighboring countries; the lone exception was the 1948 war for independence.

217. Qiang Zhai, Transplanting the Chinese Model: Chinese Military Advisors and the First Vietnam War, 1950-1954, 57 J. MIL. Hist. 689, 699 (Oct. 1993).

218. Karen Turner, Soldiers and Symbols: North Vietnamese Women and the American War, in A SOLDIER AND A WOMAN, supra note 209, at 185, 193. 